\title{
A High Temperature Polymer Electrolyte Membrane Fuel Cell Model for Reformate Gas
}

\author{
M. Mamlouk, Tiago Sousa, and Keith Scott \\ School of Chemical Engineering and Advanced Materials, Newcastle University, Newcastle, NE1 7RU, UK \\ Correspondence should be addressed to Keith Scott, k.scott@ncl.ac.uk
}

Received 2 July 2010; Accepted 25 August 2010

Academic Editor: Jiujun Zhang

Copyright () 2011 M. Mamlouk et al. This is an open access article distributed under the Creative Commons Attribution License, which permits unrestricted use, distribution, and reproduction in any medium, provided the original work is properly cited.

A one-dimensional model of a high temperature polymer electrolyte membrane fuel cell using polybenzimidazole (PBI) membranes is described. The model considers mass transport through a thin film electrolyte covering the catalyst particles as well as through the porous media. The incorporation of a thin film model describing reactant gas mass transport through electrolyte covering the electrocatalyst is shown to be an essential requirement for accurate simulation. The catalyst interface is represented using a macrohomogeneous model. The influence of carbon monoxide, carbon dioxide, and methane, which would be present in a reformate gas, is considered in terms of the effect on the anode polarisation/kinetics behaviour. The model simulates the influence of operating conditions, cell parameters, and fuel gas compositions on the cell voltage current density characteristics. The model gives good predictions of the effect of oxygen and air pressures on cell behaviour and correctly simulates the mass transport behaviour of the cell. The model with reformate gas shows that additional voltage losses associated with CO poisoning can lead to loss in voltage of tens of $\mathrm{mV}$ and thus reduction in power.

\section{Introduction}

There are numerous mathematical models of polymer electrolyte membrane fuel cells (PEMFCs) that have been reported in the literature. These include empirical (curve fitting) and zero-dimensional models which essentially coupled thermodynamic, kinetic, and resistance effects, to one/twodimensional phenomenological models. One of the early phenomenological models of a PEMFC with a Nafion membrane was developed by Bernardi and Verbrugge [1]. Since then, significant developments have been made. Models were used to study concentration and current distributions in PEMFCs [2], to map liquid saturation and temperature distributions [3] for comparison with experimental data, to solve equations describing multicomponent flow in diffusion layers and flow channels [4], or to module mass transport in porous electrodes [5].

The mass transport behaviour in PEMFC electrodes was considered to be either in a single phase [6], where no liquid water is formed, or involving two-phases [7] involving an electrolyte/water film. It was found $[8,9]$ that under the assumption of no liquid water formation, the model consistently overpredicted measured polarization behaviour.
On the other hand, results showed that the inclusion of liquid water transport greatly enhanced the predictive capability of the model and was necessary to match experimental data at high current density [10]. This could be achieved in the form of one-dimensional [11], two-dimensional [12] and three-dimensional models $[13,14]$.

In comparison, there has been little modeling of PEMFCs based on polybenzimidazole (PBI) membranes. The first proposed model [15] was a parametric model, in which a very low value of cathode porosity of $9.2 \%$ and a high value for the transfer coefficient $(\alpha)$ of 2 were used to fit the model to experimental data. However such a model could not explain the limiting current observed under air operation [15].

A second one-dimensional model assumed the Tafel approximation to describe the electrode kinetics, with a transfer coefficient equal to 0.5 whilst the exchange current density was fitted to the polarisation curves using a least square error method leading to a reaction order for oxygen equal to 0.7 [16]. The simulated polarisation curve showed a better fit for air than for oxygen, where the model underestimated the performance at the higher current densities. The influence of humidity and consequently product water 
generation on membrane conductivity was given as a reason for the observed behaviour (the model assumed constant membrane conductivity).

A third model considered a three-dimensional structure, with transfer coefficient $(\alpha)$ equal to 2 and reaction order $(\gamma)$ equal to 1 . However, once again the model failed to explain the observed difference between air and oxygen operation: with oxygen, simulation underestimated the experimental data, whilst with air operation, the simulated data overpredicted the experimental data at high current densities, where contrary to experimental results no limiting current was observed [17].

Scott et al. also proposed a one-dimensional model for PBI-based fuel cells. They described electrode kinetics by the Butler-Volmer equation and mass transport by the multicomponent Stefan Maxwell equations coupled with Darcy's law. The model had a good fit with the experimental data but failed to show limiting current under air operation [18].

Similarly, one-and two-dimensional degradation models were constructed to simulate the steady state polarisation curves recorded at different times during aging test.

The models again failed to show any apparent mass transport limitations under air operation (limiting current) and used $\alpha$ equal to 1 and $\gamma$ equal to $1[19,20]$.

The failure of the reported models to predict the mass transport limitations under air operation and therefore over estimating cell performance, particularly at high current densities, was caused by the assumption that mass transport solely occurred through the porous media. This is similar to the single phase mass transport observation discussed earlier in Nafion based PEMFC models. In reality an electrolyte (PBI/Acid) thin film surrounding the catalyst sites (particles) is present and mass transport through this phase should be considered. In this film reactants have to dissolve in the electrolyte media and diffuse through it to reach the catalytic sites, in a similar way to a two phase mass transport approach where diffusion through liquid water is considered. Diffusion through the acid electrolyte is much slower in comparison to that through porous media and can explain the observed PBI-PEMFC mass transport behaviour. The effect of the electrolyte thin film has been realised and modelled in phosphoric acid fuel cells [21].

Lobato et al. presented a model of a PBI-based high temperature PEMFC using neural networks [22]. The model can be used to elucidate the processes within the cells, by allowing optimization of materials, cells, stacks, and systems and support control systems.

This absence of a thin film model approach also explains the relatively thick catalyst layers and very low porosity used in previous reported models $[15,16]$ in attempts to compensate for the thin film effects and to try to match the experimental data. Similarly, whilst most models used a value for the reaction order equal to one, values varied from 0.5 to 2. As shown elsewhere [23], values of transfer coefficient changed with doping level. For example, at $150^{\circ} \mathrm{C}$, the lowest Tafel slope observed at the minimum doping level of 4.5 PRU (4.5 mole per repeat PBI unit) was $92 \mathrm{mV} \mathrm{dec}^{-1}(\alpha=0.91$ ) which increased to $104 \mathrm{mV} \mathrm{dec}^{-1}(\alpha=0.81)$ at a doping level of $10 \mathrm{PRU}[24,25]$ and to $90-135 \mathrm{mV} \mathrm{dec}^{-1}(\alpha=0.93-0.62)$ for phosphoric acid fuel cells [26-32].

Additionally, empirical models have been developed to study temperature effects in PBI-based PEMFCs. A change in the transfer coefficient (increase) with temperature was obtained using a nonlinear, least squares fitting method [33]. This result agrees with the finding of others [23] and similar documented behaviour in PAFC [26, 28, 29, 34].

Modelling of PBI PEMFCs will increase understanding of their behaviour, enable prediction of their performance, and assist with their operational control. Thus, a onedimensional (1D) model of the high temperature PBI-based PEMFC was developed which considered multicomponent mass transport of a reformate-based fuel, through porous media and a thin electrolyte film covering the electrocatalyst in the electrode layers. The model is a simplification of a recent two-dimensional model [35] which was solved using commercial software. The simplified model was designed to be used as a platform for a high temperature PEMFC control system. In this paper we also demonstrate that by ignoring the influence of mass transport through a thin film electrolyte over the catalyst, the PBI PEMFC model can fail to give accurate simulations of fuel cell voltage performance.

\section{Experimental}

Gas diffusion electrodes suitable for high temperature operation (nonwoven carbon cloth) incorporated with wet proofed microporous layer (obtained from Freudenberg (FFCCT, Germany) were used as substrates to deposit the catalyst layer for both anode and cathode.

A spraying machine was built to deposit reproducible catalyst layers of uniform structure/porosity. A Computer numerical control (CNC) milling machine (Sherline 2010, USA) was modified and used to provide the desired spraying pattern, whilst a fixed stainless steel spraying $(0.5 \mathrm{~mm})$ nozzle (Schlick 970S8, Germany) and associated metering valve were used to control the spray mixture (with nitrogen) and catalyst ink flow rate.

The catalyst ink was prepared by sonicating the catalyst and PTFE dispersion (60\% wt, Aldrich) in water-ethanol mixture, $50 \% \mathrm{Pt} / \mathrm{C}$ (Etek, USA), $0.4 \mathrm{mg}_{\mathrm{Pt}} \mathrm{cm}^{-2}$ in the cathode and $20 \% \mathrm{Pt} / \mathrm{C}$ (Etek, USA), $0.2 \mathrm{mg}_{\mathrm{Pt}_{\mathrm{t}}} \mathrm{cm}^{-2}$ in the anode. The final PTFE content in the catalyst layer was 40 and $20 \%$ wt for cathode and anode, respectively. The required amount of phosphoric acid (PA) was then added to the surface by means of a micropipette, and the electrodes were left for a week to cure to achieve a uniform acid distribution. A loading of 2 and $4 \mathrm{mg}_{\mathrm{H} 3 \mathrm{PO} 4} \mathrm{~cm}^{-2}$ was used for the cathode and anode, respectively.

The MEA was finally obtained by hot pressing the electrodes, onto a 5.6 mole $\%$ phosphoric acid doped PBI membrane at $150^{\circ} \mathrm{C}$ for 10 minutes with load of $40 \mathrm{~kg} \mathrm{~cm}^{-2}$.

The cell body had a $3 \mathrm{~cm} \times 3 \mathrm{~cm}$ gold-plated parallel flow fields. Mica-filled PTFE inserts were used to surround the flow fields and provide location for the O-ring seal and a dynamic hydrogen electrode (DHE). The solid state DHE consisted of two platinum wires on each side of the 
membrane located outside the O-ring: a distance of $10 \mathrm{~mm}$ away from the MEA edge to avoid side current effects (the membrane used was $\sim 50 \mu \mathrm{m}$ thick). A small current of $1.0 \mathrm{~mA} \mathrm{~cm}^{-2}(\sim 10 \mu \mathrm{A})$ was applied by means of $9.0 \mathrm{~V}$ battery connected in series with an appropriate resistance.

\section{Mathematical Model of the Fuel Cell}

The mathematical model of the fuel cell was onedimensional, and the gas flow channels were not considered. The fuel cell consisted of two-diffusion layers, anode and cathode catalyst layers, and the membrane. The assumptions adopted in the model are as follows.

(i) Steady state and isothermal operation.

(ii) Mass transport was solely due to diffusion where convection effects are negligible.

(iii) Ideal gas behaviour.

(iv) Membrane was impermeable to hydrogen and oxygen.

(v) Negligible contact resistances between components.

(vi) No membrane swelling after installation in the test cell.

(vii) Only gas phases present (no water condensation, temperatures were $120^{\circ} \mathrm{C}$ ).

(viii) Catalyst layer was thin and treated as uniform potential and concentration interface (i.e., 0D).

(ix) Isotropic macrohomogeneous porous regions.

Isothermal operation was a reasonable assumption as the test cell temperature was controlled using electrical heating and an on-off controller. Ideal gas behaviour was appropriate, as the cell was not operated at high pressure. The cell was operated at relatively high temperatures, above the normal boiling point of water, and thus it was reasonable to assume that there was no liquid saturation and that single phase behaviour applied. The flow channel was not included in the model as the boundary conditions between the flow channel and the diffusion layer were taken as the feed gas compositions. This was justified by the high gas flow stoichiometry used ( $>2.2$ at the highest current).

The macrohomogeneous model for the catalyst layer assumes that the porous electrode is an "average" of the solid electrode and the electrolyte (Figure 1). Thus, the effective conductance of the porous electrode is the weighted volume average of the respective conductance. Diffusion coefficients and other properties are similarly averaged.

The objective of the model is to determine the effect of a range of operating variables and parameters on the cell voltage of the PBI-based fuel cell. The overall cell voltage is given from a combination of the thermodynamic cell potential and voltage losses associated with Ohmic resistances in the electrodes and membrane, and kinetic losses at the anode and cathode which are influenced by mass transport restriction

$$
U_{\text {cell }}=E_{\text {rev }}-\left|\eta_{c}\right|-\left|\eta_{a}\right|-j R,
$$

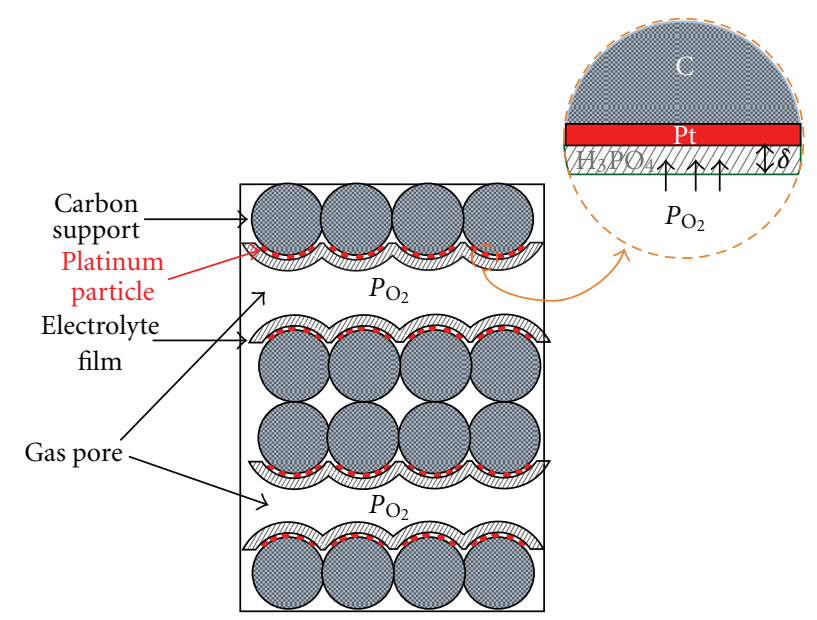

FIGURE 1: Schematic of catalyst layer using the thin film assumption.

where $E_{\text {rev }}$ is the reversible cell potential, $\eta$ refers to electrode polarisation losses, and $j R$ is the Ohmic resistance loss.

3.1. Thermodynamic Equilibrium Potential. The overall electrochemical reaction in a PEM fuel cell running on $\mathrm{H}_{2}$ as fuel and $\mathrm{O}_{2}$ as oxidant at temperature above $100^{\circ} \mathrm{C}$ can be written as

$$
\mathrm{H}_{2(g)}+\frac{1}{2} \mathrm{O}_{2(g)} \stackrel{\mathrm{Pt}}{\longrightarrow} \mathrm{H}_{2} \mathrm{O}_{(g)}
$$

Considering that thin electrolyte film covers the catalyst surface, the partial pressure of the reactants/products should be replaced with their activity in the electrolyte. The activity of hydrogen and oxygen can be replaced by their concentration in the thin film considering their activity coefficient is close to 1 (the concentrations are very low).

The thermodynamic equilibrium potential can be calculated using the Nernst equation:

$$
E_{\mathrm{rev}}=E_{\mathrm{rev}}^{0}+\frac{\mathrm{RT}}{n F} \ln \left[\frac{(\mathrm{RT})^{1.5} C_{\mathrm{H}_{2}}\left(C_{\mathrm{O}_{2}}\right)^{0.5}}{a_{\mathrm{H}_{2} \mathrm{O}}} \frac{a_{\mathrm{H}_{2} \mathrm{O}}^{0}}{P_{\mathrm{H}_{2}}^{0}\left(P_{\mathrm{O}_{2}}^{0}\right)^{0.5}}\right],
$$

where oxygen and hydrogen concentration (solubility) is obtained using Henry's law:

$$
C_{\mathrm{H}_{2}}=\frac{P_{\mathrm{H}_{2}}}{H_{T, C_{\mathrm{H}_{3} \mathrm{PO}}}^{\mathrm{H}_{2}}}, \quad C_{\mathrm{O}_{2}}=\frac{P_{\mathrm{O}_{2}}}{H_{T, C_{\mathrm{H}_{3} \mathrm{PO}_{4}}^{\mathrm{O}_{2}}}},
$$

where $P_{x}$ (atm) is the equilibrium partial pressure of species $x$ above the electrolyte film and $H^{x}\left(\right.$ atm $\left.\mathrm{cm}^{3} \mathrm{~mole}^{-1}\right)$ is Henry's constant for the given species-electrolyte $\left(\mathrm{H}_{3} \mathrm{PO}_{4}\right)$ pair at a given temperature $T$. The term RT inside the logarithm expression in (3) was introduced to convert the concentration $\mathrm{C}_{x}\left(\right.$ mole $\left.\mathrm{cm}^{-3}\right)$ into pressure units (atm) to calculate the standard cell reversal potential. 
$P_{\mathrm{O}_{2}}^{0}, P_{\mathrm{H}_{2}}^{0}$ and $\alpha_{\mathrm{H}_{2} \mathrm{O}}^{0}$ are the reference oxygen, hydrogen partial pressure, and water activity, respectively. Their values are equal to unity.

$E_{\text {rev }}^{0}$ was calculated using [36]

$$
\Delta S_{T}=-9967.35 \ln (T)+12414.83,
$$

$$
\Delta H^{f}=-238.41-0.012256 T+2.7656 \times 10^{-6} T^{2},
$$

where $\Delta H^{f}$ is in $\mathrm{kJ} \Delta S_{T}$ is in $\mathrm{JK}^{-1}$, and $T$ is in $\mathrm{K}$.

The water activity in is given by [37]

$$
a_{\mathrm{H}_{2} \mathrm{O}}=\frac{P_{\mathrm{H}_{2} \mathrm{O}}}{P_{\mathrm{H}_{2} \mathrm{O}}^{*}}=\frac{\mathrm{RH} \%}{100},
$$

where $P_{\mathrm{H}_{2} \mathrm{O}}$ is the water vapour pressure in equilibrium with the acid electrolyte, $P_{\mathrm{H}_{2} \mathrm{O}}^{*}$ is the saturation vapour pressure of pure water at the same temperature.

PBI-based fuel cells can operate under dry conditions or very low humidification; in this study the gas reactants were passed through a humidifier at room temperature $\left(18^{\circ} \mathrm{C}\right)$ prior to entering the cell $\left(\mathrm{RH}=0.36 \%\right.$ at $\left.150^{\circ} \mathrm{C}\right)$, the initial water vapour pressure (O.C.P conditions) was considered to be equal to the water saturation pressure at $18^{\circ} \mathrm{C}(291 \mathrm{~K})$, that is, $P_{\mathrm{H}_{2} \mathrm{O}}=P_{291}^{*}=0.017 \mathrm{~atm}$.

Saturated water vapour pressures were obtained from steam tables [36]. The following polynomial function presents this data in the temperature range of $273-500 \mathrm{~K}$ :

$$
\begin{aligned}
P_{\mathrm{H}_{2} \mathrm{O}}^{\mathrm{sat} *} & \\
= & \left(142.07682 T^{4}-171026.12676 T^{3}+78013638.11584 T^{2}\right. \\
& \quad-15953375633.8471 T+1231888491801.45) \times 10^{-10},
\end{aligned}
$$

where $P$ is in atm and $T$ is in Kelvin.

\subsection{Gas Transport in Porous Media}

3.2.1. Diffusion in the Porous Cathode. There were three species in the cathode gas stream, that is, oxygen, nitrogen and water.

For the purpose of this model only one-dimensional diffusion, normal to the face of the electrode, is considered. Diffusion of multicomponent gas streams through the porous carbon electrode can be described using the StefanMaxwell equation

$$
\frac{\partial X_{i}}{\partial z}=\frac{R T}{P} \sum_{j} \frac{X_{i} N_{j}-X_{j} N_{i}}{D_{i j}^{\text {eff }}} .
$$

$X_{i}$ is the mole fraction of species $i, N_{i}$ is the mole flux of species $i$, and $D_{i j}^{\text {eff }}$ is the effective binary diffusion coefficient for the pair $i-j$ in the porous medium.

$D_{i j}^{\text {eff }}$ can be calculated using the corrected Slattery-Bird correlation [38] to account for the porosity/tortuosity effects with the Bruggeman correlation [18]

$$
\begin{aligned}
& D_{i j}^{\mathrm{eff}} \\
& =\frac{a}{P}\left(\frac{T}{\sqrt{T_{c, i} T_{c, j}}}\right)^{b}\left(P_{c, i} P_{c, j}\right)^{1 / 3}\left(T_{c, i} T_{c, j}\right)^{5 / 12}\left(\frac{1}{M_{i}}+\frac{1}{M_{j}}\right)^{1 / 2} \varepsilon^{\tau}
\end{aligned}
$$

where $T_{c}$ and $P_{c}$ are the gas critical temperature and pressure, respectively. $M$ is the gas molecular weight, $\varepsilon$ is the porosity and $\tau$ is the tortuosity. $a$ and $b$ are constants, $a$ is 0.0002745 for diatomic gases and 0.000364 for water vapour and $b$ is 1.832 for diatomic gases and 2.334 for water vapour.

The species' flux can be given as follows:

nitrogen (inert species):

$$
N_{\mathrm{N}_{2, g}}=0 \text {, }
$$

oxygen:

$$
N_{\mathrm{O}_{2, g}}=\frac{j}{4 F}
$$

water:

$$
N_{\mathrm{H}_{2} \mathrm{O}, g}=\frac{-j}{2 F}
$$

where $j$ is the current density per geometric electrode area and $\mathrm{F}$ is Faraday's constant.

Substituting the species flux in (8), we obtain

$$
\begin{aligned}
& \frac{\mathrm{d} X_{\mathrm{N}_{2}}}{\mathrm{~d} z}=\frac{R T}{p} X_{\mathrm{N}_{2}}\left(\frac{N_{\mathrm{O}_{2, g}}}{D_{\mathrm{N}_{2}, \mathrm{O}_{2}}^{\text {eff }}}+\frac{N_{\mathrm{H}_{2} \mathrm{O}, g}}{D_{\mathrm{N}_{2,}, \mathrm{H}_{2} \mathrm{O}}^{\mathrm{eff}}}\right) \\
& \frac{\mathrm{d} X_{\mathrm{H}_{2} \mathrm{O}}}{\mathrm{d} z} \\
& \quad=\frac{R T}{p}\left[X_{\mathrm{H}_{2} \mathrm{O}}\left(\frac{N_{\mathrm{O}_{2, g}}}{D_{\mathrm{O}_{2}, \mathrm{H}_{2} \mathrm{O}}^{\text {eff }}}\right)-N_{\mathrm{H}_{2} \mathrm{O}}\left(\frac{X_{\mathrm{O}_{2,}}}{D_{\mathrm{O}_{2}, \mathrm{H}_{2} \mathrm{O}}^{\mathrm{eff}}}+\frac{X_{\mathrm{N}_{2,}}}{D_{\mathrm{N}_{2}, \mathrm{H}_{2} \mathrm{O}}^{\mathrm{eff}}}\right)\right] .
\end{aligned}
$$

At the catalyst layer where $Z$ is thickness of the gas diffusion electrode we can write [36] 


$$
\begin{aligned}
& X_{\mathrm{N}_{2}}=X_{\mathrm{N}_{2}}^{0} \mathrm{e}^{\left[(R T / p)\left(\left(N_{\mathrm{O}_{2}, \mathrm{~g}} / D_{\mathrm{N}_{2}, \mathrm{O}_{2}}^{\text {eff }}\right)+\left(N_{\mathrm{H}_{2} \mathrm{O}, 8} / D_{\mathrm{N}_{2}, \mathrm{H}_{2} \mathrm{O}}^{\mathrm{eff}}\right) Z\right]\right.}
\end{aligned}
$$

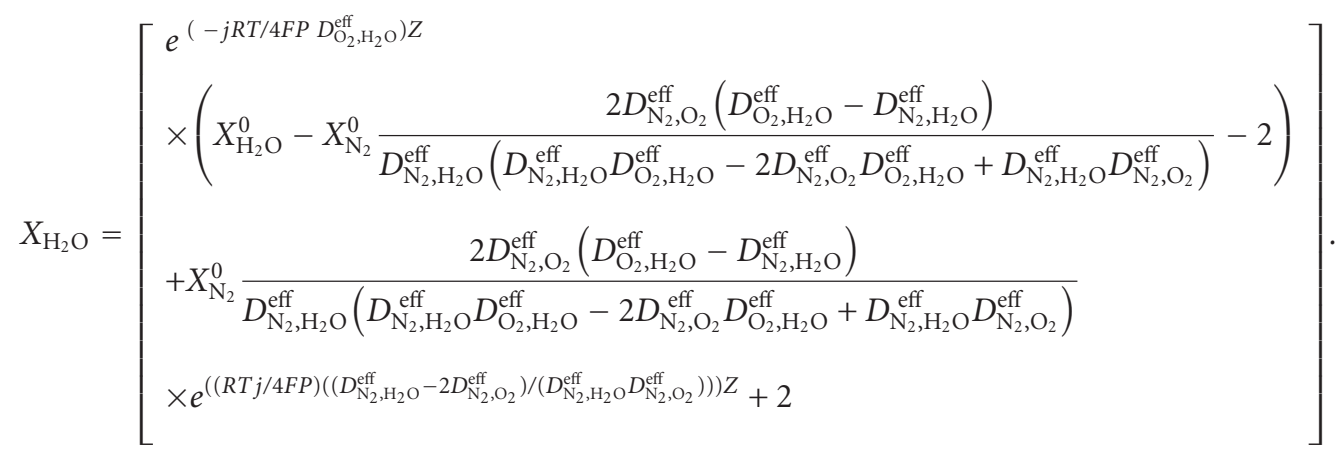

Oxygen molar fraction is given by

$$
X_{\mathrm{O}_{2}}=1-X_{\mathrm{N}_{2}}-X_{\mathrm{H}_{2} \mathrm{O}} .
$$

3.2.2. Diffusion in the Porous Anode. The reformate anode gas feed can consist of a mixture of $\mathrm{CH}_{4}, \mathrm{CO}_{2}, \mathrm{CO}, \mathrm{H}_{2} \mathrm{O}$ and $\mathrm{H}_{2}$. For the five component gas anode species, we can write balances as

$$
\begin{aligned}
& \frac{\mathrm{d} X_{\mathrm{CO}_{2}}}{\mathrm{~d} z}=\frac{R T}{p} X_{\mathrm{CO}_{2}}\left(\frac{N_{\mathrm{H}_{2}, g}}{D_{\mathrm{H}_{2}, \mathrm{CO}_{2}}^{\text {eff }}}\right), \\
& \frac{\mathrm{d} X_{\mathrm{H}_{2} \mathrm{O}}}{\mathrm{d} z}=\frac{R T}{p} X_{\mathrm{H}_{2} \mathrm{O}}\left(\frac{N_{\mathrm{H}_{2}, g}}{D_{\mathrm{H}_{2,} \mathrm{H}_{2} \mathrm{O}}^{\text {eff }}}\right), \\
& \frac{\mathrm{d} X_{\mathrm{CO}}}{\mathrm{d} z}=\frac{R T}{p} X_{\mathrm{CO}}\left(\frac{N_{\mathrm{H}_{2}, g}}{D_{\mathrm{H}_{2}, \mathrm{CO}}^{\text {eff }}}\right), \\
& \frac{\mathrm{d} X_{\mathrm{CH}_{4}}}{\mathrm{~d} z}=\frac{R T}{p} X_{\mathrm{CH}_{4}}\left(\frac{N_{\mathrm{H}_{2}, g}}{D_{\mathrm{H}_{2}, \mathrm{CH}}}\right),
\end{aligned}
$$

where $N_{\mathrm{CH}_{4, g}}=0, N_{\mathrm{CO}_{2, g}}=0, N_{\mathrm{CO}, g}=0$, and $N_{\mathrm{H}_{2} \mathrm{O}, \mathrm{g}}=0$,

$$
N_{\mathrm{H}_{2, g}}=\frac{j}{2 F} \text {. }
$$

Solution of the above equations leads to

$$
\begin{gathered}
X_{\mathrm{CO}_{2}}=X_{\mathrm{CO}_{2}}^{0} e^{\left[(R T / p)\left(N_{\mathrm{H}_{2}, g} / D_{\mathrm{H}_{2}, \mathrm{CO}}\right) Z\right]}, \\
X_{\mathrm{H}_{2} \mathrm{O}}=X_{\mathrm{H}_{2} \mathrm{O}}^{0} e^{\left[(R T / p)\left(N_{\mathrm{H}_{2}, g} / D_{\mathrm{H}_{2}, \mathrm{H}_{2} \mathrm{O}}^{\mathrm{eff}}\right) Z\right]}, \\
X_{\mathrm{CO}}=X_{\mathrm{CO}}^{0} e^{\left[(R T / p)\left(N_{\mathrm{H}_{2}, g} / D_{\mathrm{H}_{2}, \mathrm{CO}}^{\mathrm{eff}}\right) Z\right]}, \\
X_{\mathrm{H}_{2}}=1-X_{\mathrm{CO}_{2}}-X_{\mathrm{H}_{2} \mathrm{O}}-X_{\mathrm{CO}}-X_{\mathrm{CH}_{4}} .
\end{gathered}
$$

3.3. Transport through Thin Film Electrolytes. The macrohomogeneous model for the catalyst layer assumed that the catalyst layer is an "average" of the solid electrode and the electrolyte. Thus, the effective conductance of the catalyst layer was the weighted volume average of the respective conductance: diffusion coefficients and film thickness are similarly averaged, and so forth.
Oxygen transport from the porous media to the catalyst active surface area occurred through a thin acid film covering the catalyst agglomerates. The film provides proton conductive paths from the catalyst active sites to the membrane. The average film thickness $\delta$ was estimated using the following equation:

$$
\delta=\frac{m_{\mathrm{H}_{3} \mathrm{PO}_{4}} / \rho_{\mathrm{H}_{3} \mathrm{PO}_{4}}}{S_{C}+S_{P t}} .
$$

$m$ is the total mass added of $\mathrm{H}_{3} \mathrm{PO}_{4}$ per unit area(loading), $\rho$ is the density, and $S_{c} / S_{P t}$ is the surface area of carbon/platinum per unit area covered by the electrolyte.

Values of oxygen diffusion in phosphoric acid ( $98 \% \mathrm{wt}$ ) were reported to be $30 \times 10^{-6} \mathrm{~cm}^{2} \mathrm{~s}^{-1}$, an order of magnitude higher than that of doped PBI (doping level of 6PRU) $3.2 \times$ $10^{-6} \mathrm{~cm}^{2} \mathrm{~s}^{-1}$ at $150^{\circ} \mathrm{C}$. Similar values of dissolved oxygen concentration was obtained for doped PBI (doping level of 6 PRU) $0.68 \times 10^{-6}$ mole $\mathrm{cm}^{-3}$ and for $95 \%$ wt phosphoric acid 0.5 mole $\mathrm{cm}^{-3}$ at $150^{\circ} \mathrm{C}$ and atmospheric pressure [24].

Liu et al. studied oxygen reduction at the platinum/phosphoric acid doped PBI interface, and found that oxygen diffusion was increased by increasing the volume fraction of amorphous (free) $\mathrm{H}_{3} \mathrm{PO}_{4}$ (i.e., doping level). They also suggested that the crystalline PBI regions were not involved in proton or oxygen transport $[24,25]$.

To determine the oxygen/hydrogen concentration at the catalyst surface, we can derive from Fick's law for diffusion:

$$
\begin{aligned}
& \frac{N_{\mathrm{O}_{2}}}{S_{P t \text {-cathode }}}=\frac{-D_{\mathrm{O}_{2}}^{\mathrm{H}_{3} \mathrm{PO}_{4}}\left(C_{\mathrm{O}_{2}-P t}-C_{\mathrm{O}_{2} \text { (dissolve) }}\right)}{\delta_{\text {Cathode }}}, \\
& \frac{N_{\mathrm{H}_{2}}}{S_{P t \text {-anode }}}=\frac{-D_{\mathrm{H}_{2}}^{\mathrm{H}_{3} \mathrm{PO}_{4}}\left(\mathrm{C}_{\mathrm{H}_{2}-P t}-\mathrm{C}_{\mathrm{H}_{2} \text { (dissolve) }}\right)}{\delta_{\text {Anode }}} .
\end{aligned}
$$

$N$ is the molar flux (geometric area), $C_{P t}$ is the reactant concentration on the catalyst surface, and $C_{\text {dissolve }}$ is the equilibrium reactant concentration in the acid film at the studied temperature. $S_{P t}$ as mentioned earlier was the real platinum surface area (ESA) per unit area that was covered with an electrolyte film (also known as the roughness factor $R F)$.

Due to insufficient data on hydrogen solubility in phosphoric acid at high temperature, hydrogen solubility 
was considered similar to that of oxygen [39] at the same conditions (pressure, temperature and phosphoric acid concentration).

Similarly, for the hydrogen diffusion coefficient in phosphoric acid electrolyte we can write [40]:

$$
D_{\mathrm{H}_{2}}^{\mathrm{H}_{3} \mathrm{PO}_{4}}=D_{\mathrm{O}_{2}}^{\mathrm{H}_{3} \mathrm{PO}_{4}} \sqrt{\frac{M_{\mathrm{O}_{2}}}{M_{\mathrm{H}_{2}}}}=4 D_{\mathrm{O}_{2}}^{\mathrm{H}_{3} \mathrm{PO}_{4}} .
$$

Experimental data (not shown) showed that with air at atmospheric pressure, the product $D C_{\text {dissolve }}$ decreased slowly with temperature, whilst for the same electrode under air at 1 bar (relative) the product $D C_{\text {dissolve }}$ exhibited a maximum at $150^{\circ} \mathrm{C}$. This effect was caused by variations in diffusion coefficient $D$ and Henry's constant $H$ at a given temperature with changes in phosphoric acid concentration and consequently water partial pressure above the electrolyte film; in other words the concentration and viscosity of phosphoric acid at a given temperature depended on the humidity content.

Klinedinst et al. studied oxygen solubility and diffusivity in hot phosphoric acid [41]. They suggested that both gas diffusivities and solubilities exhibit exponential reciprocal temperature dependencies, that is,

$$
\begin{gathered}
D_{\mathrm{O}_{2}}^{\mathrm{H}_{3} \mathrm{PO}_{4}}=A \exp \left(-\frac{E_{a}}{R T}\right), \\
C_{\mathrm{O}_{2}}^{\text {dissolved }}=B \exp \left(-\frac{\Delta H_{\mathrm{O}_{2}}^{\text {solu }}}{R T}\right) .
\end{gathered}
$$

$A$ and $B$ are pre-exponential factors (given in the Appendix), $E_{a}$ is the diffusion activation energy, and $\Delta H$ is the enthalpy of solution. Both $E_{a}$ and $\Delta H$ change with the concentration of phosphoric acid.

3.3.1. Diffusion, Temperature, and Phosphoric Acid Concentration. A second-order polynomial was fitted using a least square error technique to fit the data obtained by Klinedinst et al. [41], for the activation energy of oxygen in phosphoric acid at different acid weight concentrations $(W)$. The correlation equation is given by

$$
\begin{aligned}
& E_{a}\left(\mathrm{kcal} \mathrm{mole}^{-1}\right) \\
& \quad=-0.011607142857 W^{2}+1.9642142857 W-75.376
\end{aligned}
$$

The high values of the diffusion activation energy were assigned to the extensive hydrogen bond network and high viscosity of concentrated $\mathrm{H}_{3} \mathrm{PO}_{4}$ [42]. This also explained the increase in activation energy with increasing phosphoric acid concentration.

The calculated diffusion values were in the range of $\left(10^{-5}-10^{-6} \mathrm{~cm} \mathrm{~s}^{-1}\right)$ depending on the temperature and phosphoric acid concentration; values were in good agreement with values obtained in the literature $[32,41,43,44]$.
3.3.2. Solubility, Temperature, and Phosphoric Acid Concentration. A third-order polynomial was built to fit oxygen enthalpy of solution data obtained from [41]

$$
\begin{aligned}
\Delta H(\mathrm{kcal})=( & -0.003125 W^{3}+0.8371429 W^{2} \\
& -74.95179 W+2244.786) .
\end{aligned}
$$

The enthalpy of solution $(-\Delta H$, as $\Delta H<0$ for $W<96 \% \mathrm{wt})$ decreased with increase in phosphoric acid concentration until it reached negative values at $96 \%$ wt. This means that a smaller decrease in the solubility of oxygen in phosphoric acid with temperature will occur as the acid concentration increases from $85 \%$ wt to $95 \% \mathrm{wt}$; beyond this concentration a slow increase in solubility with temperature will occur.

$C_{\mathrm{O}_{2}}$ and $D_{\mathrm{O}_{2}}$ can be obtained from (26) and (25) for a given acid weight concentration. Substituting their values into (20) and (21) will finally lead to $C_{P t}$, the oxygen concentration on the catalyst surface required in the ButlerVolmer kinetic equation.

\subsubsection{Phosphoric Acid Concentration, Temperature, and Water} Vapour Pressure. MacDonald and Boyack [45] studied the density, conductivity and equilibrium water vapour pressure of concentrated phosphoric acid from room temperature to $170^{\circ} \mathrm{C}$. Data from their work was used to determine phosphoric acid concentrations (wt \%) at a given temperature, and water vapour pressure.

To obtain a good fit without using polynomials of very high order, they suggested expressing concentrations as mole percent $X$, instead of $W$ (wt \%) using the formula

$$
X=\frac{0.01 W}{0.01 W+0.0544(100-W)}
$$

At any given concentration, a linear relation was obtained between $\log \left(P_{\mathrm{H}_{2} \mathrm{O}} / \mathrm{mm} \mathrm{Hg}\right)$ the equilibrium water vapour pressure and $1 / T\left({ }^{\circ} \mathrm{C}^{-1}\right)$ :

$$
\log \left(P_{\mathrm{H}_{2} \mathrm{O}}\right)=-a T^{-1}+b
$$

Two functions were built to correlate $a$ and $b$ with $X, \%$ mole; values of $a$ and $b$ with the relevant functions are given in the appendix.

During simulation of the model in this work, $X$ and $W$ were continuously updated based on water vapour pressure (or relative humidity) and temperature. $W$ was obtained from $X$ using

$$
W=\frac{98 X}{0.98 X+(18.016-0.18016 X)} .
$$

From (28) and (29), it can be seen that $P_{\mathrm{H}_{2} \mathrm{O}}$ (or humidity) is highly dependent on phosphoric acid concentration at the typical low humidity conditions for PBI-based PEMFCs gas feed. This means that phosphoric acid concentrations will vary greatly with the water produced by the fuel cell (logarithmic relation). 
TABLE 1: Variation in values of transfer coefficient with temperature from references $[23,28,34,47]$.

\begin{tabular}{lcccc}
\hline $\mathrm{T}^{\circ} \mathrm{C}$ & $\begin{array}{c}\text { Reference [23] } \\
\text { 16PRU }\end{array}$ & $\begin{array}{c}\text { Extrapolated from } \\
\text { [34] } \mathrm{H}_{3} \mathrm{PO}_{4}\end{array}$ & $\begin{array}{c}\text { Obtained from } \\
{[28] \mathrm{H}_{3} \mathrm{PO}_{4}}\end{array}$ & $\begin{array}{c}\text { Extrapolated from } \\
{[47] \mathrm{H}_{3} \mathrm{PO}_{4}}\end{array}$ \\
\hline 100 & 0.5864 & 0.7624 & 0.6022 & 0.6098 \\
120 & 0.6724 & 0.8304 & 0.6302 & 0.6398 \\
150 & 0.8014 & 0.9324 & 0.6722 & 0.6848 \\
175 & 0.9089 & 1.0174 & 0.7072 & 0.7223 \\
\hline
\end{tabular}

3.4. Kinetics. The Butler-Volmer equation was used to describe the kinetics at the anode and cathode

$$
\begin{aligned}
& j_{a}=i_{0, a}\left(\exp \left(\frac{-\alpha_{R d, a} F}{R T}\left(\eta_{a}\right)\right)-\exp \left(\frac{\alpha_{O x, a} F}{R T}\left(\eta_{a}\right)\right)\right), \\
& j_{c}=i_{0, c}\left(\exp \left(\frac{-\alpha_{R d, c} F}{R T}\left(\eta_{c}\right)\right)-\exp \left(\frac{\alpha_{O x, c} F}{R T}\left(\eta_{c}\right)\right)\right),
\end{aligned}
$$

where the subscripts $a$ and $c$ are for anode and cathode, respectively. $\alpha$ is the transfer coefficient, $i_{0}$ is the exchange current density at the studied conditions per $\mathrm{Pt}$ unit area given by (32) below.

Values of $\alpha$ can be obtained from the Tafel slope $b=$ $2.3 R T / \alpha F$. It was shown earlier [23] that the value of $\alpha$ changes with doping level for example, at $150^{\circ} \mathrm{C}$ the lowest Tafel slope observed at the minimum doping level of 4.5 PRU was $92 \mathrm{mV} \mathrm{dec}^{-1}(\alpha=0.91)$ increasing to $104 \mathrm{mV} \mathrm{dec}^{-1}(\alpha=$ $0.81)$ at a doping level of 10 PRU $[24,25]$.

Oxygen reduction in PBI-free electrodes environment (or for PBI electrodes with very high doping level) is the same as that in phosphoric acid, while for PBI-based electrodes, appropriate transfer coefficient should be chosen, depending on the doping level [23].

Various Tafel slopes have been reported for phosphoric acid fuel cells in the range of 90 and $135 \mathrm{mV} \mathrm{dec}^{-1}(\alpha=0.93-$ $0.62)$ at $150^{\circ} \mathrm{C}$ [26-32]. An average value of alpha equal to $0.75\left(112 \mathrm{mV} \mathrm{dec}^{-1}\right)$ was considered in this work. The closest available experimental data for a PBI-free environment at $150^{\circ} \mathrm{C}$ is from half cells results with a high doping (16 PRU) PBI electrode at temperature of $140^{\circ} \mathrm{C}$ [23]; the reported alpha value was 0.75 , which agrees with the chosen reported alpha's value for phosphoric acid.

Whilst the discussed values for alpha were for a temperature of $150^{\circ} \mathrm{C}$, alpha values vary with operating cell temperature (Table 1). Appleby [26] reported variations of $\alpha$ from 0.56 at $25^{\circ} \mathrm{C}$ to 0.66 at $136^{\circ} \mathrm{C}$ in $85 \%$ wt phosphoric acid. Similarly, O'Grady et al. [34] reported values from 0.53 at $25^{\circ} \mathrm{C}$ to 0.68 at $70^{\circ} \mathrm{C}$ in $85 \%$ wt phosphoric acid. Haung et al. [27] reported $\alpha$ value ( $85 \%$ wt $\mathrm{H}_{3} \mathrm{PO}_{4}$ ) of $0.47,0.61$, and 0.67 at temperatures of 25,100 , and $150^{\circ} \mathrm{C}$, respectively. Kunz and Gruver [46] reported $\alpha=0.94$ at $160^{\circ} \mathrm{C}(96 \% \mathrm{wt}$ $\mathrm{H} 3 \mathrm{PO} 4)$ using $\mathrm{Pt} / \mathrm{C}$ as catalyst.

The variation of dependency with temperature was expressed as [48]

$$
\alpha=a+c T
$$

where $a$ and $c$ are constants. Values for $c$, the rate change of alpha with temperature, were 0.0014 [28], 0.0015 [47], 0.0034 [34], and 0.0043 [23] (PBI 16 PRU).
The value of alpha and its variation with temperature depend on the catalyst treatment and the impurity content in the acid $[29,47]$.

The exchange current density was obtained using

$$
i_{0}=i_{0}^{\mathrm{ref}} a_{c} L_{c}\left(\frac{C_{P t}}{C_{P t}^{\mathrm{ref}}}\right)^{\gamma} \exp \left[-\frac{E_{C}}{R T}\left(1-\frac{T}{T_{\mathrm{ref}}}\right)\right] .
$$

$i_{0}^{\mathrm{ref}}\left(\mathrm{A} \mathrm{cm}_{P t}^{-2} \mathrm{ESA}\right)$ is the exchange current density measured at a reference temperature $T_{\text {ref }}$ and reference dissolved oxygen concentration (solubility) $C_{\text {ref. }} C_{P t}$ is the reactant concentration on the catalyst surface calculated from (20) (or (21) for hydrogen). $a_{c}\left(\mathrm{~m}_{P t}^{2} \mathrm{~g}^{-1}\right)$ is the catalyst-specific accessible electrochemical surface area (covered by electrolyte) in the electrode measured using cyclic voltammetry (31.55 and $35.45 \mathrm{~m}^{2} \mathrm{~g}^{-1}$ for cathode and anode electrodes utilizing $50 \% \mathrm{Pt} / \mathrm{C}$ and $20 \% \mathrm{Pt} / \mathrm{C}$, resp.), which corresponded to $50 \%-30 \%$ of the given value by the manufacture (ETEK, USA) of $128 \mathrm{~m}^{2} \mathrm{~g}^{-1}$ for $20 \% \mathrm{Pt} / \mathrm{C}$ and $86 \mathrm{~m}^{2} \mathrm{~g}^{-1}$ for $50 \%$ $\mathrm{Pt} / \mathrm{C}$ when placed in the electrode structure [49]. $a_{c}$ can also be estimated by multiplying the ionomer's volume fraction in the catalyst layer by the catalyst ESA.

$L_{c}$ is the catalyst loading, which corresponds to the weight of platinum per unit geometric area $\left(\mathrm{mg} \mathrm{cm}^{-2}\right)$. The product $a_{c} L_{c}$ is the roughness factor (dimensionless), which is the $P t$ electrochemical surface area divided by the electrode geometric area, referred to earlier as $S_{P t}$. The units of the product $i_{0}^{\text {ref }} S_{P t}$ or $i_{0}$ will be $\mathrm{Acm}^{-2}$ (current density per electrode geometric area).

$\gamma$ is the pressure coefficient or the reaction order with respect to oxygen in phosphoric acid/PBI, a value of 1 (first order) was reported in $[24,32]$.

$E_{c}$, the activation energy of oxygen reduction in hot phosphoric acid, was found to be independent of phosphoric acid concentration [47 equals to $72.4 \mathrm{~kJ} \mathrm{~mole}^{-1}$ [32]]. Values for $i_{0}^{\text {ref }}$ vary in the literature (Table 2), depending on the temperature, phosphoric acid concentration, and the dissolved oxygen concentration. Most values were in the range of $10^{-8}$ A $\mathrm{cm}_{\mathrm{Pt}}^{-2}$, and $i_{0}$ value from $[31,47]$ was used.

Similarly, a value of $i_{0}^{\text {ref }}=0.144 \mathrm{~A} \mathrm{~cm}^{-2}$ at $160^{\circ} \mathrm{C}$ $\left(C_{\mathrm{H} 2}^{\mathrm{ref}} 2.11 * 10^{-4}\right.$ mole L $\left.^{-1}\right), E_{a}=16.9 \mathrm{~kJ} \mathrm{~mole}^{-1}, \alpha=0.5$, and $\gamma=1$ for hydrogen oxidation in phosphoric acid was obtained from [39].

3.5. Reformate Fuel. One of the major advantages of high temperature operation in PEMFCs is the CO tolerance and therefore the systems ability to operate with reformate gas feed without considerable loss in performance. Reformate gas composition varies depending on the hydrocarbon 
TABLE 2: Reported exchange current densities for oxygen reduction in phosphoric acid.

\begin{tabular}{|c|c|c|c|c|}
\hline$i_{0} / \mathrm{A} \mathrm{cm}_{P t}^{-2}$ & $\mathrm{H}_{3} \mathrm{PO}_{4} / \mathrm{wt} \%$ & $\mathrm{~T} /{ }^{\circ} \mathrm{C}$ & $C_{\mathrm{O}_{2}} /$ mole L $^{-1}$ & References \\
\hline $6 * 10^{-8}$ & 96 & 160 & $4.13 * 10^{-4^{\mathrm{a}}}$ & {$[46]$} \\
\hline $2.8 * 10^{-7}$ & 85 & 136 & $2.61 * 10^{-4^{\mathrm{a}}}$ & {$[47]$} \\
\hline $4 * 10^{-8}$ & 85 & 96 & $3.94 * 10^{-4^{\mathrm{a}}}$ & {$[31,47]$} \\
\hline $2.4 * 10^{-8}$ & 85 & 136 & $2.61 * 10^{-4^{\mathrm{a}}}$ & {$[26]$} \\
\hline $3.8 * 10^{-9}$ & 98 & 100 & $0.996 * 10^{-4}$ & {$[31]$} \\
\hline $3.9 * 10^{-8}$ & 98 & 125 & $0.971 * 10^{-4}$ & {$[31]$} \\
\hline $2.63 * 10^{-8}$ & 98 & 150 & $1.07 * 10^{-4}$ & {$[31]$} \\
\hline $8 * 10^{-8}$ & 85 & 60 & $6.23 * 10^{-4^{\mathrm{a}}}$ & [27] \\
\hline $1.7 * 10^{-6}$ & 85 & 160 & $2.11 * 10^{-4^{\mathrm{a}}}$ & [27] \\
\hline $1 * 10^{-8}$ & 85 & 120 & $3.05 * 10^{-4^{\mathrm{a}}}$ & {$[26]$} \\
\hline $1.6 * 10^{-8}$ & 85 & 136.1 & $2.61 * 10^{-4^{\mathrm{a}}}$ & [29] \\
\hline
\end{tabular}

${ }^{\mathrm{a} C a l c u l a t e d ~ c o n c e n t r a t i o n s ~ f r o m ~(24) ~ a n d ~(26) . ~}$

used in the reformation process. A typical diesel reformate composition contains $3 \% \mathrm{CH}_{4}, 19 \% \mathrm{CO}_{2}, 2.2 \% \mathrm{CO}$, and $20 \% \mathrm{H}_{2} \mathrm{O}$, and the rest is hydrogen.

The model was developed to account for the poisoning effect of $\mathrm{CO}$ and possibly methane on the catalyst surface. $\mathrm{CO}$ poisoning effects on $\mathrm{Pt}$ in phosphoric acids system have been studied by several groups $[40,41,50,51]$. There are two main effects of $\mathrm{CO}$ on anode performance; the first is a dilution effect already accounted for in the Butler-Volmer equation, and the other is a kinetic effect arising from a reduction in active surface area because of $\mathrm{CO}$ adsorption on the $\mathrm{Pt}$ surface.

The rate determining step for hydrogen oxidation is the dissociation reaction (Volmer) giving rise to the secondorder dependency of hydrogen oxidation rate on surface coverage and Vogel et al. [39] suggested the following equation:

$$
i_{0}^{\mathrm{CO}}=i_{0}\left(1-\theta_{\mathrm{CO}}\right)^{2}
$$

$i_{0}^{\mathrm{CO}}$ is the exchange current density for hydrogen oxidation after CO poisoning, $i_{0}$ is the exchange current density for hydrogen oxidation without $\mathrm{CO}$ presence, and $\theta_{\mathrm{CO}}$ is the surface coverage by $\mathrm{CO}$ given by

$$
\theta_{\mathrm{CO}}=\frac{\text { Volume Hydrogen adsorbed after } \mathrm{CO}}{\text { Volume Hydrogen adsorbed before CO }} \text {. }
$$

$\theta_{\mathrm{CO}}$ is reported to vary linearly with $\ln \left(\mathrm{CO} / \mathrm{H}_{2}\right)[39,40$, 50], although various values for the constants of their relation dependency have been reported. Kohlmayr and Stonehart [51] suggested that CO coverage is independent of temperature, in the range from 100 to $150^{\circ} \mathrm{C}$ in phosphoric acid media. Considering the heat of $\mathrm{CO}$ adsorption, it is expected that $\mathrm{CO}$ coverage should exhibit an exponential dependency on temperature. Dhar et al. [50] suggested the following equation for the variation of $\mathrm{CO}$ coverage variation with temperature in $\mathrm{H}_{3} \mathrm{PO}_{4}$

$$
\theta_{\mathrm{CO}}=19.9 \exp \left[-7.69 \times 10^{-3} T\right]-0.085 \ln \frac{[\mathrm{CO}]}{\left[\mathrm{H}_{2}\right]} \text {. }
$$

In this work, (35) was used to express CO coverage on a platinum surface and its variation with $\mathrm{CO}$ content, temperature, and hydrogen content.

In the case of carbon dioxide only its dilution effect was considered in the model, ignoring any effect of reduction of carbon dioxide to carbon monoxide by hydrogen at the studied temperature [52].

Under the circumstances of insufficient data on the effect of methane on the platinum surface in phosphoric acid, two cases were considered.

Case 1. Sustersic et al. [53] showed that methane adsorption on platinum surface started from a potential $0.2 \mathrm{~V}$ versus NHE and reached a maximum adsorption peak at $0.25 \mathrm{~V}$ (versus NHE). In HT-PEMFC the anode potential does not exceed $50 \mathrm{mV}$ (even at high current densities of $1.5 \mathrm{~A} \mathrm{~cm}^{-2}$ ) which is far below the minimum potential suggested for methane adsorption. Niedrach [54] found that methane had low adsorption on platinum (0.28 at STP) compared to that of other saturated hydrocarbons (moderate) except ethane, while unsaturated hydrocarbons exhibited very high adsorption: 0.79 (at STP) for propylene and 0.91 (at STP) for cyclopropane. This suggests that consideration should be taken for nonsaturated hydrocarbons in the reformate gas, and their concentration should be determined.

Case 2. Taylor and Brummer [55] studied methane adsorption in $12 \mathrm{M} \mathrm{H}_{3} \mathrm{PO}_{4}$ at $130^{\circ} \mathrm{C}$. Similarly, they found a maximum adsorption peak at $0.25 \mathrm{~V}$ versus NHE; however, on the contrary, they observed methane adsorption at low potentials of $0.1 \mathrm{~V}$ and lower (versus NHE) some $50 \%$ of that at $0.25 \mathrm{~V}$. This suggests that methane adsorption might occur even at the low operating anode potentials.

Hsieh and Chen [56] studied methane oxidation on $\mathrm{Pt}$ in $1 \mathrm{M} \mathrm{H}_{2} \mathrm{SO}_{4}$. The rest potential was $100 \mathrm{mV}$ versus NHE, the exchange current density was $10^{-7} \mathrm{~A} \mathrm{~cm}^{-2}$ at $80^{\circ} \mathrm{C}$ and 1 atm methane, and the activation energy was $125 \mathrm{~kJ} \mathrm{~mole}^{-1}$. The activation energy was 3.5 larger than that of hydrogen oxidation, and the exchange current density was six orders of magnitude lower than that of hydrogen 
oxidation. The rate of methane oxidation compared to hydrogen is negligible, so it can be treated as an inert species with only dilution/concentration effect (Case 1) or considering the worse case scenario as adsorption similar to that for CO (Case 2).

3.6. Gas Crossover Polarisation. In reality the observed cell OCP is lower than the estimated value from the thermodynamics $E_{\text {rev }}$ due to the effect of crossover and other phenomena (carbon corrosion, platinum oxidation, $\mathrm{Pt}-\mathrm{OH}$, etc.). Considering crossover current density $j_{\text {crossover }}$ (at $\operatorname{OCP} j \neq i_{0}$ ) leading to an overvoltage $\eta_{\text {crossover, }}$, given by

$$
\begin{aligned}
& j_{\text {crossover }} \\
& =i_{0, c}\left(\exp \left(\frac{-\alpha F}{R T}\left(\eta_{\text {crossover }}\right)\right)-\exp \left(\frac{\alpha F}{R T}\left(\eta_{\text {crossover }}\right)\right)\right),
\end{aligned}
$$

where $\alpha$ is the transfer coefficient and $i_{o}$ is the exchange current density. form:

The above equation can be expressed in the following

$$
\eta_{\text {crossover }}=\frac{-R T}{\alpha F} \ln \left[\frac{j_{\text {crossover }}}{2 i_{0, c}}+\sqrt{1+\left(\frac{j_{\text {crossover }}}{2 i_{0, c}}\right)^{2}}\right] .
$$

The observed open circuit will be equal to $E_{\text {rev }}+\eta_{\text {crossover }}$; typically for a PBI membrane with thickness $80-40 \mu \mathrm{m}$ the observed $\mathrm{OCP}$ with oxygen at $150^{\circ} \mathrm{C}$ was in the range of $0.88-1.0 \mathrm{~V}$. OCP values of $0.95 \mathrm{~V}[33]$ and $0.9 \mathrm{~V}[15,17]$ have been previously used for PBI PEMFC models.

It should be stressed here that the observed OCP cannot replace $E_{\text {rev }}$ as $i_{o}$ is solely measured at $E_{\text {rev }}$. The effects of crossover on polarisation curves can be ignored, as it is only important at very small currents and becomes negligible when polarising the electrode, where the total current $i+$ $i_{\text {crossover }}$ becomes equal to $i\left(i \gg i_{\text {crossover }}\right)$ as can be seen in (38) in other words the overvoltage losses due to hydrogen crossover become negligible

$$
\begin{aligned}
\eta_{\text {crossover }}=\frac{-R T}{\alpha F} \ln \left[\frac{\left(j+j_{\text {crossover }} / 2 i_{0, c}\right)}{\left(j / 2 i_{0, c}\right)+\sqrt{1+\left(j / 2 i_{0, c}\right)^{2}}}\right. \\
\\
\left.\frac{+\sqrt{1+\left(j+j_{\text {crossover }} / 2 i_{0, c}\right)^{2}}}{\left(j / 2 i_{0, c}\right)+\sqrt{1+\left(j / 2 i_{0, c}\right)^{2}}}\right] .
\end{aligned}
$$

3.7. Conductivity and IR Losses. To express the proton conductivity $\sigma$ of acid doped PBI at different temperatures a modified Arrhenius equation has been suggested for polymer/acid (salt) complexes [57-61]

$$
\sigma \cdot T=A \exp \left(\frac{-B}{R\left(T-T_{0}\right)}\right)
$$

Expressions for $A$, the pre-exponential factor, and $B$, the activation energy, which are humidity and doping level dependant are given in the appendix and the corresponding constants to calculate $A$ and $B$ are given in [58, Table 4].
Polynomial functions were fitted for $A$ and $B$ based on the relative humidity at a given doping level (membrane doping level of 5.6 PRU in this case), given in the Appendix.

The conductivity obtained from (39) along with the membrane thickness of $(40 \mu \mathrm{m})$ were used to determine the $I R$ losses through the membrane. On the other hand the $I R$ losses (protonic) through the catalyst layer were obtained from the catalyst layer thickness $(15 \mu \mathrm{m})$ and the effective phosphoric acid conductivity (product of phosphoric acid conductivity at the studied condition and its volume fraction in the electrode). The conductivity of phosphoric acid varies with temperature $T$ and relative humidity $(\mathrm{RH})$ (or phosphoric acid concentration $W(\mathrm{wt} \%))$.

The following functions for conductivity were given [45] for $84 \leq W \leq 94 \%$ :

$$
\begin{aligned}
K(S \cdot \mathrm{cm})= & 1.01365-1.21548 \times 10^{-2} W \\
& -\left(1.5447 \times 10^{-7}-6.42463 \times 10^{-5} W\right) T .
\end{aligned}
$$

$$
\begin{aligned}
& \text { For } 95 \leq W \leq 99 \%: \\
& \begin{aligned}
K(S \cdot \mathrm{cm}) \\
=-3.45285+7.77294 \times 10^{-2} W-4.50762 \times 10^{-4} W^{2} \\
\quad-\left(6.24637 \times 10^{-2}-1.387186 \times 10^{-3} W\right. \\
\left.\quad+7.18336 \times 10^{-6} W^{2}\right) T .
\end{aligned}
\end{aligned}
$$

Matlab V.7.3 and Simulink V.6.5 (The MathWorks, U.K) equipped with Ordinary Differential Equation solver (ODE 45 ) were used to solve the model governing equations. The model results were compared to experimental data for a $50 \%$ $\mathrm{Pt} / \mathrm{C}\left(0.4 \mathrm{mg}_{\mathrm{Pt}} \mathrm{cm}^{-2}\right)$ cathode and 20\% Pt/C (0.2 $\left.\mathrm{mg}_{\mathrm{Pt}} \mathrm{cm}^{-2}\right)$ anode. The experimental data were collected using a cathodic sweep from OCP to $0 \mathrm{~V}$ under pseudosteady-state conditions. High resolution experimental data were sampled every $1.0 \mathrm{mV}$ step in order to allow for good comparison with the model results.

\section{Results and Discussion}

4.1. Influence of the Thin Film. We carried out simulations of the PBI-based fuel cell using a model in which thin film characteristics were not included. The model was based on a two-dimensional architecture [35] in which flow channel effects can be accounted for but with high gas stoichiometries reduces to a $1 \mathrm{D}$ model. The model in general predicts the effects of parameters such as temperature and gas pressure as shown in Figure 2, that is, performance improved with higher temperature and with higher oxygen partial pressure. However, as shown in Figure 3 under conditions where experimentally a limiting current density was observed, the model failed to predict this behaviour and overpredicted performance. Consequently for modelling PBI PEMFC the influence of mass transport of reactants through an electrolyte film is required as shown in the following sections. 


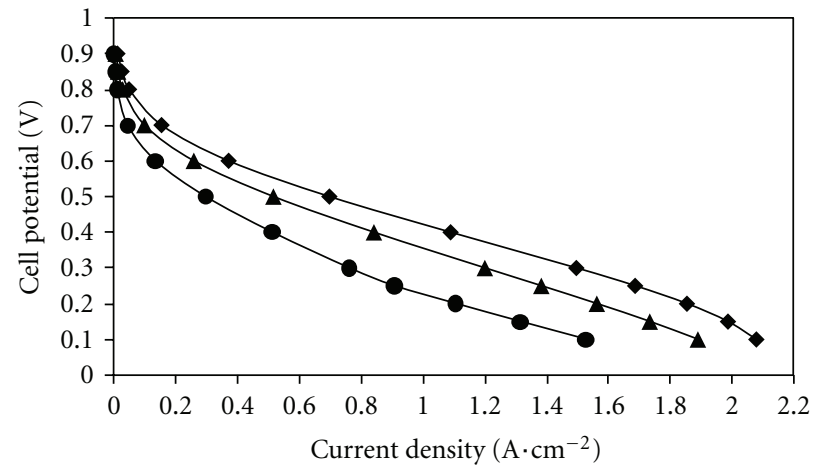

(a) Temperature effect. (a) $\backslash$ : $170^{\circ} \mathrm{C}$; (b) $\Delta T: 150^{\circ} \mathrm{C}$; (c) $\bullet T: 120^{\circ} \mathrm{C}$

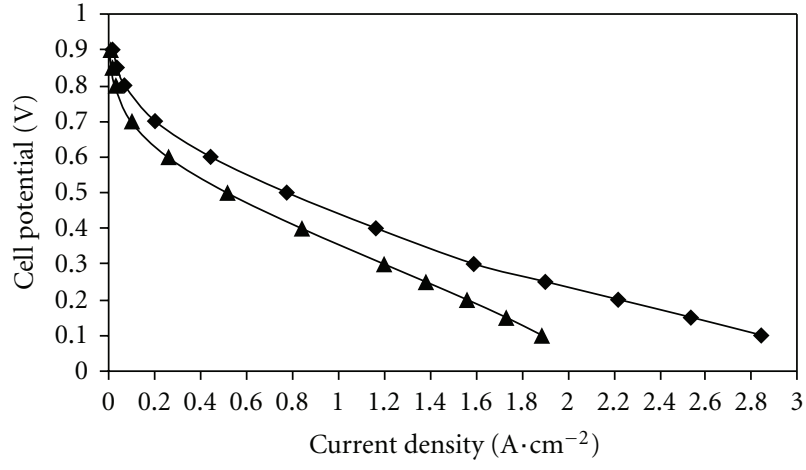

(b) Pressure effect. (a) p: 2 bar; (b) $\boldsymbol{\Delta}$ atmospheric pressure

Figure 2: Effect of temperature and pressure on polarization curves for a PEM fuel cell. 50\% Pt/C at the cathode and 20\% Pt/C at the anode. Air was used at the cathode and hydrogen at the anode at atmospheric pressure.

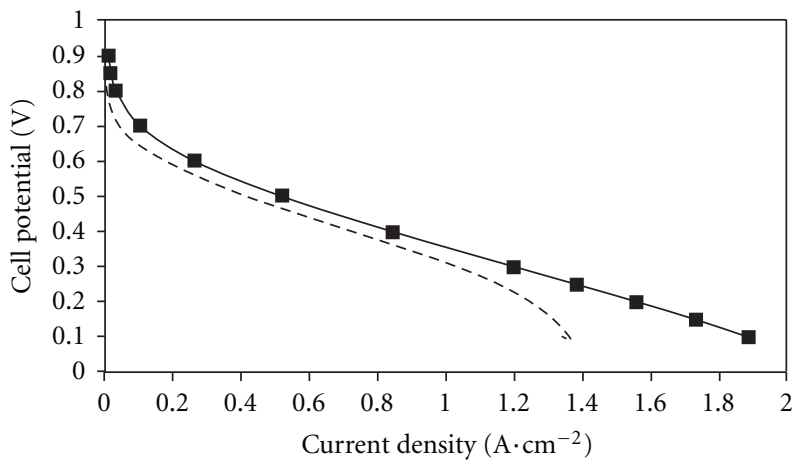

FIGURE 3: Comparison between modelled and experimental data for a PEM fuel cell utilising 50\% Pt/C at the cathode and 20\% Pt/C at the anode at $150^{\circ} \mathrm{C}$. Air was used at the cathode and hydrogen at the anode at atmospheric pressure. (a) model; (b) - - experimental.

4.2. Oxygen Partial Pressure Effects. Figure 4 compares simulated and experimental data for PBI-based HT-PEMFC at different oxygen partial pressures: from air (atm) to air (1 bar) and pure oxygen. Large increases in voltage were seen in both modelled and experimental data due to enhancement in kinetics and mass transport when increasing oxygen concentration (partial pressure). This effect was due to the low oxygen permeability in hot concentrated phosphoric acid. The experimental observed limiting current increased from $\left(\sim 1.4\right.$ to $\left.2.1 \mathrm{~A} \mathrm{~cm}^{-2}\right)$ when doubling oxygen partial pressure ( $1 \mathrm{~atm}$ to $1.99 \mathrm{~atm})$. The model data and the experimental data were in good agreement. However, small differences were observed in the slope of the polarisation curves, at high current densities, where the model overestimated the cell performance with air and air ( 1 bar pressure) whilst not under oxygen operation.

The slope of the polarisation curves is affected by a combination of kinetic, mass transport, and $I R$ effects. The observed difference of the slope at high current densities in this case was probably caused by unknown kinetic or

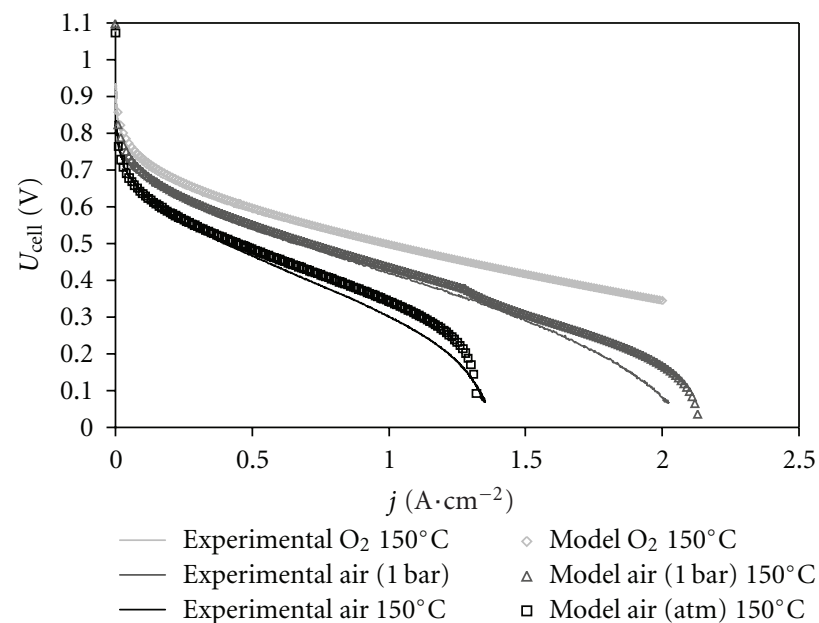

FIGURE 4: Comparison between modelled and experimental results for HT-PEMFC utilising 50\% Pt/C at the cathode and 20\% Pt/C on the anode at temperature of $150^{\circ} \mathrm{C}$ and various pressures; alpha value of 0.75 was used for the cathode.

mass transport effects, and not $I R$ effects, as a good match in the slope was observed at high current densities under oxygen operation. In order to improve the fit between the experimental data and the model prediction, it would seem that a correction at high current densities should be made to the kinetic effect and mass transport (higher $\gamma$ ).

To introduce increased mass transport losses, the reaction order $(\gamma)$ with respect to oxygen in phosphoric acid was increased from the commonly reported value of 1.0 [32] to 1.375; values above 1.0 have also been reported for $\mathrm{PBI} / \mathrm{H} 3 \mathrm{PO} 4$ interface [25]. The reported values of reaction order were measured at constant overvoltage $\eta$ (and not constant voltage $E$ ), that is, they were measured from the exchange current density ratios $(\eta=0)$, where $i_{0}$ was measured at equilibrium potential $E_{\mathrm{rev}}$ which in turn is affected by a concentration change (Nernst equation) as will be discussed shortly. 


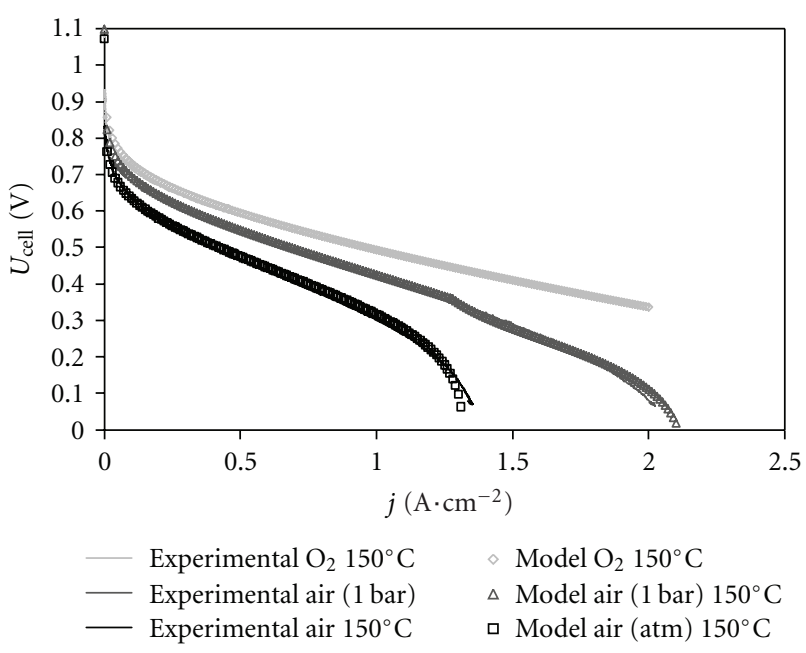

FIGURE 5: Comparison between modelled and experimental results for HT-PEMFC utilising 50\% Pt/C at the cathode and 20\% Pt/C on the anode at temperature of $150^{\circ} \mathrm{C}$ and various pressures; alpha value of 0.75 and $\gamma=1.375$ was used for the cathode.

Figure 5 shows the effect of the higher reaction order (1.375) on the cell voltage polarisation curve and maintaining the standard value of alpha (0.75). An improvement in the simulation and experimental data agreement at various oxygen pressures is seen, where the model predictions followed the experimental data very closely even at high current densities and different oxygen concentration

A higher value of gamma than 1.0 can be caused by factors such as the following.

\section{(i) Thermodynamic Effect of Oxygen Concentration Losses:}

Whilst the oxygen concentration influence was accounted for in the Butler-Volmer (32), the cell reversible potential was considered constant over the cell polarisation where the equilibrium concentrations at rest potential (zero current) was considered. An additional change in the reversible potential will occur due to lower oxygen concentrations (see (3)). This shift is equal to $(R T / 2 F) \ln$ $\left(C_{\mathrm{O}_{2}} / C_{\mathrm{O}_{2}}^{0}\right)$ as given by the Nernst equation.

Thus, rather than writing the $\mathrm{BV}$ equation for high current densities as:

$$
\eta_{c}=\frac{R T}{\alpha F} \ln \left(\frac{j}{i_{0}}\right)+\frac{\gamma R T}{\alpha F} \ln \left(\frac{C_{\mathrm{O}_{2}}}{C_{\mathrm{O}_{2}}^{0}}\right) .
$$

The overpotential is given by:

$$
\eta_{c}=\frac{R T}{\alpha F} \ln \left(\frac{j}{i_{0}}\right)+\frac{\gamma R T}{\alpha F} \ln \left(\frac{C_{\mathrm{O}_{2}}}{C_{\mathrm{O}_{2}}^{0}}\right)+\frac{R T}{2 F} \ln \left(\frac{C_{\mathrm{O}_{2}}}{C_{\mathrm{O}_{2}}^{0}}\right) .
$$

This can be rewritten as:

$$
\eta_{c}=\frac{R T}{\alpha F} \ln \left(\frac{j}{i_{0}}\right)+\frac{\gamma^{\prime} R T}{\alpha F} \ln \left(\frac{C_{\mathrm{O}_{2}}}{C_{\mathrm{O}_{2}}^{0}}\right) .
$$

Where $\gamma^{\prime}$ is equal to $(\gamma+\alpha) / 2$ or in this case $(1+0.75) / 2=$ 1.375 , the value used for gamma in the latest simulation. (ii) Losses of Surface Area (ESA) due to Oxygen Starvation: Losses in the accessible electrochemical surface area might occur due to oxygen starvation, where at very low oxygen concentrations it will not be able to reach parts of the catalyst surface even though it is available for reaction (covered with electrolyte). This effect would lead to a further decline in performance at high current densities and low oxygen concentrations (in comparison to gamma $=1$ ). Unfortunately, such an effect is not accounted for in this model and is one of the limitations of the macrohomogeneous model, where it is assumed that the average accessible catalyst layer is constant.

However if such effects are present then, the ESA can be written as function of $\ln \left(C_{\mathrm{O}_{2}} / C_{\mathrm{O}_{2}}^{0}\right)$ which would effectively cause an increase in apparent reaction order.

4.3. Porous Media Effects. The effect of mass transport losses due to diffusion through porous media can be seen by comparing cell performances using air $\left(\mathrm{O}_{2}-\mathrm{N}_{2}\right)$ and heleox mixture $\left(\mathrm{O}_{2}-\mathrm{He}\right)$ as oxidant at the cathode. While both mixtures contain the same oxygen concentration $\left(X_{\mathrm{O}_{2}}=\right.$ 0.21 ), the inert gas used in the mixture is different. The binary diffusion coefficients of oxygen-helium and waterhelium are four and eight times higher than those of oxygennitrogen and water-nitrogen, respectively.

The enhancement in cell performance observed when switching from air to heleox is caused by mass transport enhancement through the porous structure. Generally a larger difference between the limiting currents using air or heleox is due to a greater contribution of the porous media mass transport losses or the smaller the value of $(\varepsilon \tau)$. Similarly, to the earlier observation (oxygen partial pressure effect), using $\alpha=0.75$ and $\gamma=1$, the model provided good predictions of cell performance; however it overestimated the performance at high current densities.

Figure 6 shows that when increasing the gamma value to 1.375, whilst maintaining the standard value of alpha (0.75), an improvement in the model fit with the experimental data is achieved. The model predictions followed the experimental data very closely even at high current densities and with different oxidant: air or heleox.

The model also successfully estimated the limiting current values with air and heleox. This suggests that the chosen value for porosity $\varepsilon$ of $22 \%(\tau=1.5[18])$ is appropriate for the studied electrode.

4.4. Thin Film and Electrolyte Distribution. As discussed earlier incorporation of the thin film in the model is essential to enhance the model ability to predict cell performance at high current densities and low oxygen concentrations. The electrolyte content is a crucial parameter for optimising the three-phase boundaries and therefore the electrode performance. Increasing the electrolyte content in the electrode will increase the accessible ESA and increase the film thickness whilst reducing the porosity. The electrolyte film thickness can be estimated using (19). Values of 50 and $160 \mathrm{~nm}$ were obtained for the studied cathode and anode, respectively. 


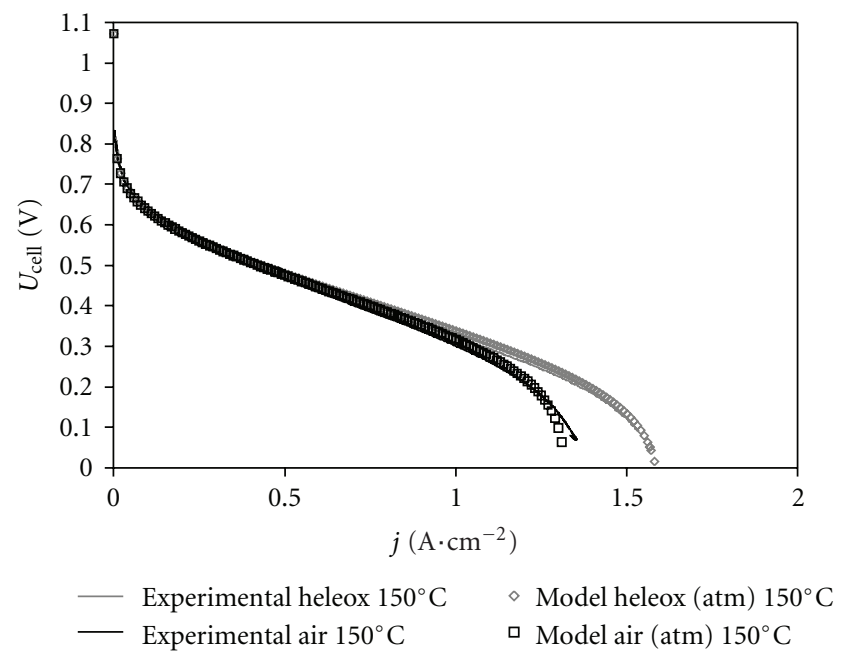

Figure 6: Comparison between modelled and experimental results for $\mathrm{HT}-\mathrm{PEMFC}$ utilising $50 \% \mathrm{Pt} / \mathrm{C}$ at the cathode and $20 \% \mathrm{Pt} / \mathrm{C}$ on the anode at temperature of $150^{\circ} \mathrm{C}$ using air and heleox mixture; alpha value of 0.75 and $\gamma=1.375$ was used for the cathode.

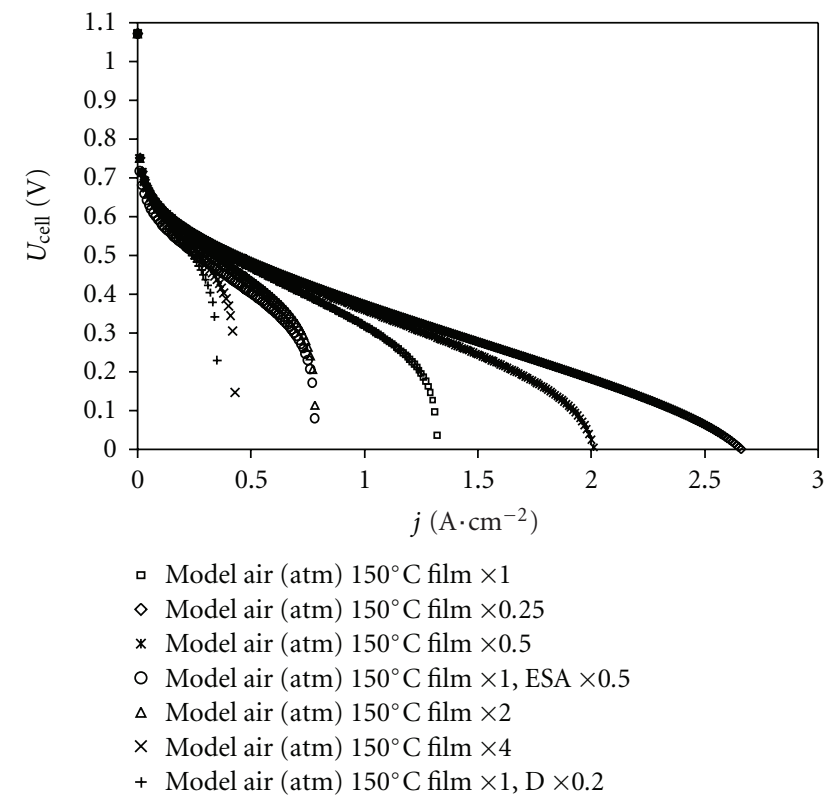

Figure 7: The effect of cathode film thickness and electrolyte type/content on cell performance utilising 50\% $\mathrm{Pt} / \mathrm{C}$ at the cathode and $20 \% \mathrm{Pt} / \mathrm{C}$ on the anode at temperature of $150^{\circ} \mathrm{C}$ using air; alpha value of 0.75 and $\gamma=1.375$ was used for the cathode.

Figure 7 shows the effect of cathode film thickness on cell performance under air operation. Increasing the film thickness by factors of 2 and 4 led to a severe impact on cell performance even at relatively small current densities and as a consequence the limiting current fell from 1.32 to 0.78 and $0.43 \mathrm{~A} \mathrm{~cm}^{-2}$, respectively. This shows the crucial impact of electrolyte content on cathode and cell overall performance. Similarly, decreasing the film thickness enhanced the overall performance due to enhancement in mass transport and correspondingly an increase in the observed limiting current. This behaviour agreed with reported experimental observations [62], where electrodes with the highest observed limiting current showed the best overall performance over the entire potential range.

While the above analysis assumed fixed ESA, conductivity, and porosity, in practice there is a minimum film thickness below which the ESA will fall rapidly (conductivity also will fall, while porosity will increase).

Considering a case where the film thickness is maintained constant and the ESA is halved, this corresponds to decrease in the acid content (volume fraction) in the cathode layer by half. Such a change led to a dramatic fall in cell performance in both the kinetic (activation) and the mass transport regions of the polarisation curve where the limiting current decreased from $\sim 1.4$ to $0.78 \mathrm{~A} \mathrm{~cm}^{-2}$. On the other hand if the electrolyte content is increased (for example doubled) above the optimum content, where no further significant increase in ESA is achieved, then the overall performance will decrease due to mass transport effects caused by a doubling in the film thickness.

This behaviour agrees with the experimental finding of the importance of acid loading (content) in the cathode layer [62]: excess acid (high doping case) led to severe mass transport limitations, and heat treatment (low doping case) led to dramatic impact on both the kinetic, and mass transport losses.

The model showed (data not reported) that a variation in anode film thickness had a less crucial effect on performance than that of the cathode film, even though the anode initial film thickness was $\sim 3$ times higher than that of the cathode: no limiting current was observed with oxygen operation (no mass transport limitation from the cathode) up to $2 \mathrm{~A} \mathrm{~cm}^{-2}$ (no experimental data is available beyond $2 \mathrm{~A} \mathrm{~cm}^{-2}$ due to instrument limitations). The behaviour was caused by the high hydrogen concentration in the anode feed (pure hydrogen) in comparison to air operation in the cathode. The model predictions show that for the anode catalyst layer, the acid content was far less crucial than that of the cathode; the anode catalyst layer was able to accommodate more acid before considerable mass transport limitations became visible. Also a low PBI content in the anode catalyst layer $(5 \% \mathrm{wt})$ did not result in mass transport limitation up to the studied current density of $2 \mathrm{~A} \mathrm{~cm}^{-2}$. However, a larger PBI content did lead to severe mass transport limitations and an observed limiting current (due to anode) at low current densities.

4.5. Comparison with $1 / 2 D$ Model. Figure 8 shows the effect of oxidant on the predictions of a 2D model which includes a thin film model [35]. This model as would be expected gives accurate simulations of the experimental data. The differences between predictions of this model and the simpler model described in this paper (Figures 5 and 6) are very small and fall in the range of error of estimation of the model parameters (from experimental data) and the experimental cell voltage/current density measurements. Thus under conditions when excess oxidant and air are 


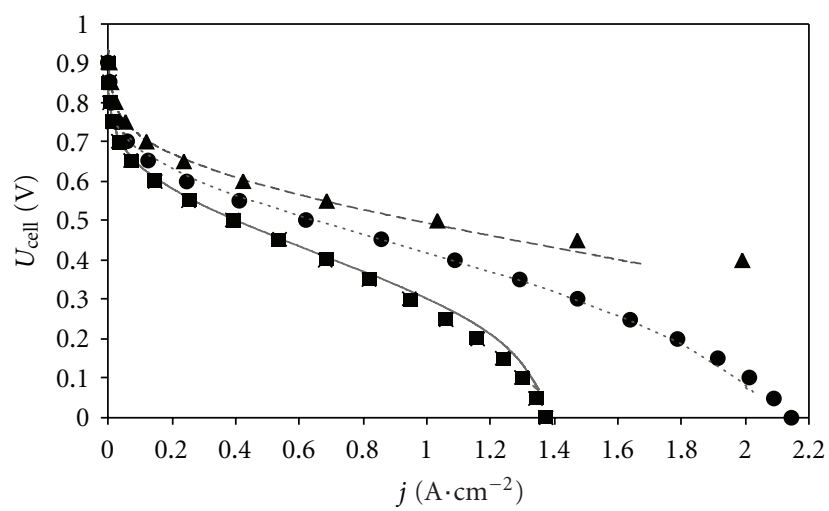

(a)

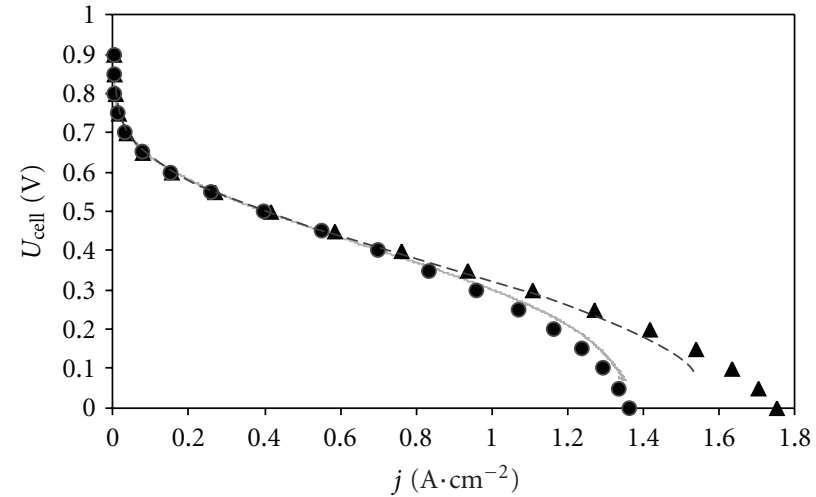

(b)

FIGURE 8: Model prediction from a 2/1D thin film film model of the PBI PEMFC. 50\% Pt/C at the cathode and 20\% Pt/C at the anode at $150^{\circ} \mathrm{C}$. (a) Effect of oxidant gas and at various pressures (i) - Experimental air atmospheric pressure, (ii) $\square$ model air atmospheric pressure, (iii) ... experimental air 1 bar, (iv) • model air 1 bar, (v) - - experimental $\mathrm{O}_{2}$ atmospheric pressure, and (vi) $\boldsymbol{\Delta}$ model $\mathrm{O}_{2}$ atmospheric pressure. (b) Effect of using air or helox as oxidant. (i) - Experimental air, (ii) • model air, (iii) - - experimental helox, and (iv) $\boldsymbol{\Delta}$ model helox.

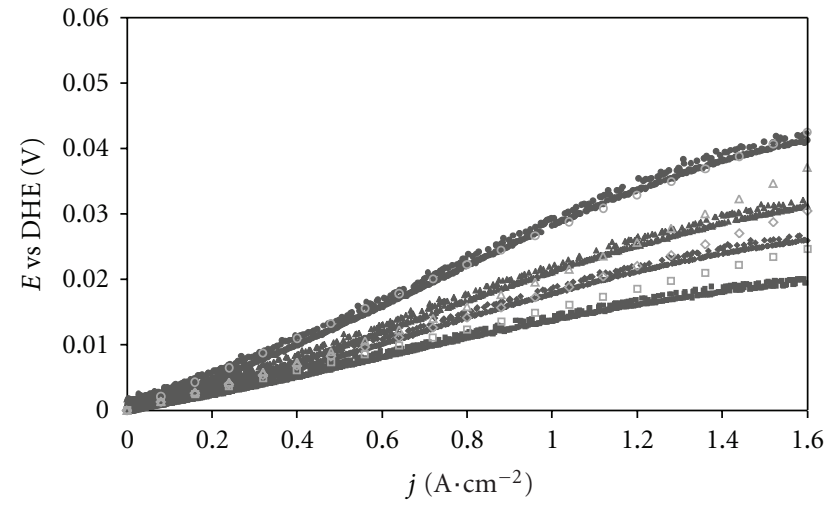

- Experimental pure $\mathrm{H}_{2} 150^{\circ} \mathrm{C}$

- Experimental $20 \% \mathrm{CO}_{2} 150^{\circ} \mathrm{C}$

- Experimental $33 \% \mathrm{CO}_{2} 150^{\circ} \mathrm{C}$

- Experimental $2.5 \% \mathrm{CO} 150^{\circ} \mathrm{C}$

- Model pure $\mathrm{H}_{2} 150^{\circ} \mathrm{C}$

- Model $2.5 \% \mathrm{CO} 150^{\circ} \mathrm{C}$

$\diamond$ Model $22 \% \mathrm{CO}_{2} 150^{\circ} \mathrm{C}$

$\triangle$ Model $33 \% \mathrm{CO}_{2} 150^{\circ} \mathrm{C}$

FIGURE 9: Experimental $\mathrm{CO}$ and $\mathrm{CO}_{2}$ effects on anode performance at $150^{\circ} \mathrm{C}$ with platinum $(20 \% \mathrm{Pt} / \mathrm{C})$ loading of $0.2 \mathrm{mg}_{\mathrm{Pt}} \mathrm{cm}^{-2}$, compared to the model results.

used, it would seem acceptable to adopt a simpler model as described in this paper. When however incorporating the effect of gas supplied near stoichiometric requirements a more rigorous 2D (or 3D) model should be used.

4.6. Diesel Reformate. The use of diesel reformate instead of pure hydrogen is expected to have its major influence on the behaviour of the anode polarization, and thus this factor is considered in the simulations.

A comparison between the model and experimental $\mathrm{CO}$ and $\mathrm{CO}_{2}$ effects on the anode performance at $150^{\circ} \mathrm{C}$ is shown in Figure 9. The voltage losses at a current density of $1.5 \mathrm{~A} \mathrm{~cm}^{-2}$ were for both experimental and modelled data 8,12 , and $22 \mathrm{mV}$ when switching from pure hydrogen to
$20 \%, 33 \%$ vol $\mathrm{CO}_{2}$, and $2.5 \% \mathrm{vol} \mathrm{CO}$, respectively. Similarly, $\mathrm{Li}$ et al. showed that small voltage losses of less than $10 \mathrm{mV}$ with current densities up to $1.3 \mathrm{~A} \cdot \mathrm{cm}^{-2}$ were observed for $\mathrm{PBI} / \mathrm{H}_{3} \mathrm{PO}_{4}$ with $\mathrm{CO}$ levels of 1 and $3 \%$ at temperatures of 150 and $200^{\circ} \mathrm{C}$, respectively [52]. This results in losses of power density of 12,18 , and $33 \mathrm{~mW} \mathrm{~cm}^{-2}$, respectively. Very good agreement was observed (Figure 9) between the experimental and the model data over the entire studied compositions. A small deviation was observed at high current densities where the experimental data approached a plateau (curve) whilst the model data continued in the expected, close to linear variation. This behaviour was also observed with pure hydrogen. Due to fast hydrogen oxidation kinetics and high hydrogen concentrations used, IR losses were the main contribution for anode losses at high current densities. Whilst no water flux through the membrane was considered in this model, the flux of gaseous water product from the cathode to the anode will occur at high current densities, driven by the large gradient in water content which in turn will cause the observed enhanced proton conductivity of the anode (anode feedin this experimental case- had a very low humidity $R H=$ $0.36 \%$ at $150^{\circ} \mathrm{C}$ with a humidifier temperature of $\sim 16^{\circ} \mathrm{C}$ ). Water permeability of $1 \times 10^{-14}$ to $3 \times 10^{-14} 200 \mathrm{~cm}^{3}$ (STP) $\mathrm{m} \mathrm{m}^{-2} \mathrm{~s}^{-1} \mathrm{~Pa}^{-1}$ for phosphoric acid doped PBI membranes was reported [37] at elevated temperatures of $125-150^{\circ} \mathrm{C}$.

Figure 10 shows the simulated anode performance at $150^{\circ} \mathrm{C}$ with various reformate compositions considering Case 1 (concentration effect only for methane).

The following observations can be drawn.

(i) Methane has a worse dilution effect than $\mathrm{CO}_{2}$, at the same concentration of $22 \%$. An increase in anode potential in comparison to pure hydrogen of $11 \mathrm{mV}$ was observed at $1.5 \mathrm{~A} \mathrm{~cm}^{-2}$ when using methane (a power density loss of $16.5 \mathrm{~mW} \mathrm{~cm}^{-2}$ ) compared to that of $8 \mathrm{mV}$ when using $\mathrm{CO}_{2}$ (loss of $12 \mathrm{~mW} \mathrm{~cm}^{-2}$ ). 


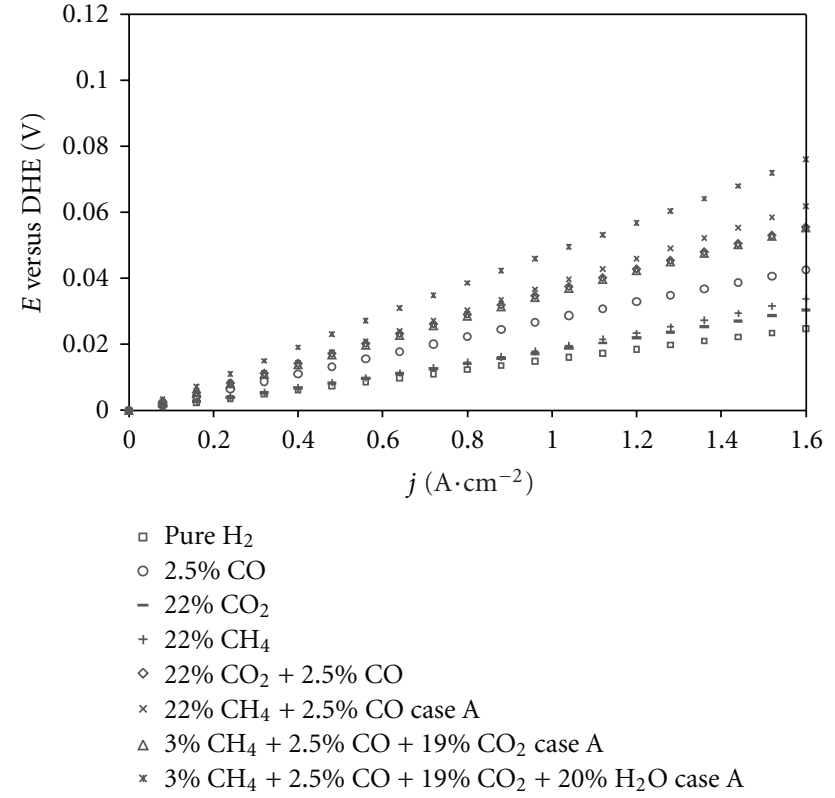

Figure 10: Modelled reformate composition effect on anode performance at $150^{\circ} \mathrm{C}$.

(ii) The addition of the separate dilution effect of inert species $\left(\mathrm{CO}_{2}, \mathrm{H}_{2} \mathrm{O}\right.$, etc. $)$ with the poisoning and dilution effects of poisonous species (CO) does not add up to the simultaneous effects of a mixture of both species. This is explained by the $\mathrm{CO}$ coverage as proportional to $\ln \left([\mathrm{CO}] /\left[\mathrm{H}_{2}\right]\right)[40,50]$, which means that any fall in hydrogen concentration, due to dilution by inert species, will lead to higher $\mathrm{CO}$ coverage at the same $\mathrm{CO}$ concentration and therefore enhance the poisoning effect.

(iii) $\mathrm{A} 30 \mathrm{mV}$ potential difference between pure hydrogen and the diesel reformate composition at a current density of $1.5 \mathrm{~A} \mathrm{~cm}^{-2}$ was obtained considering only the dilution effect for methane (Case 1), reflecting a fall in power density of $45 \mathrm{~mW} \mathrm{~cm}^{-2}$.

(iv) The potential difference between pure hydrogen and diesel reformate increases to $50 \mathrm{mV}$ at the same current density, when adding $20 \%$ water to the gas stream (no information was available for water concentration in the reformate mixture). However, $20 \%$ water content should be reasonable for steam reforming case, which means a loss of $75 \mathrm{~mW} \mathrm{~cm}^{-2}$ in power density at $1.5 \mathrm{~A} \mathrm{~cm}^{-2}$. Water dilution is significant as the hydrogen concentration falls from $75 \%$ to $55 \%$ leading to intensified CO poisoning effects, whilst initially increasing water concentration in the stream is thought to be beneficial in terms of proton conductivity enhancement. The maximum allowed water content in the gas steam should also be considered to avoid acid losses (washout) and corresponding losses of system overall conductivity.

Figure 11 shows the modelling results for anode performance at $150^{\circ} \mathrm{C}$ under various reformate compositions, considering

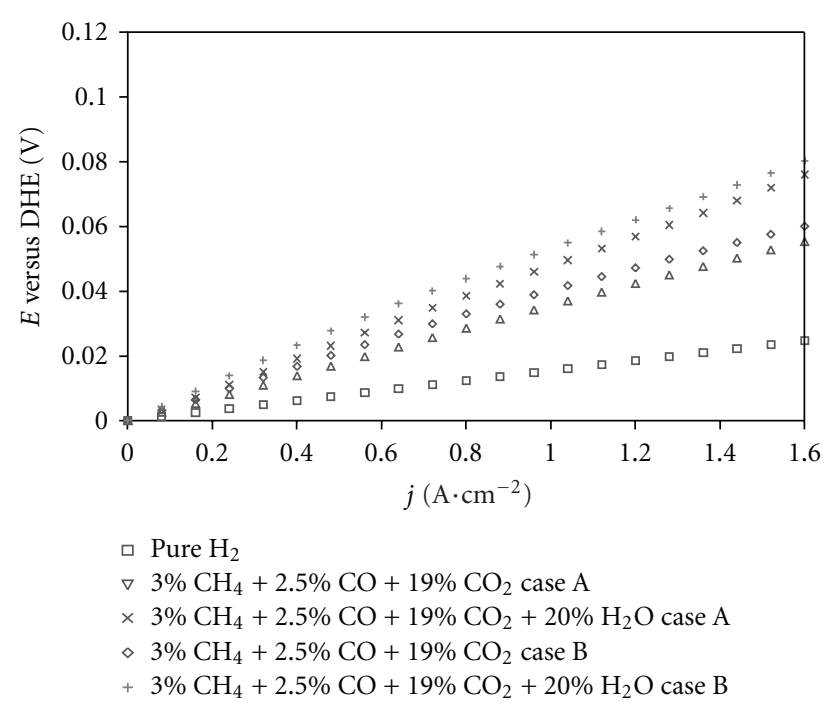

Figure 11: Effect of methane on anode potential modelled as inert species (Case 1), and as poisoning species (CO) (Case 2), with various reformate compositions at $150^{\circ} \mathrm{C}$.

TABLE 3

\begin{tabular}{cccc}
\hline$a_{0}$ & 639.232 & $b_{0}$ & 7.594 \\
$a_{1}$ & $4.761 \times 10^{-5}$ & $b_{1}$ & $2.793 \times 10^{-7}$ \\
$a_{2}$ & $1.135 \times 10^{-2}$ & $b_{2}$ & $6.744 \times 10^{-5}$ \\
$a_{3}$ & 0.969 & $b_{3}$ & $5.714 \times 10^{-3}$ \\
$a_{4}$ & 33.253 & $b_{4}$ & 0.210 \\
\hline
\end{tabular}

TABLE 4

\begin{tabular}{cccc}
\hline$k_{0}^{a}$ & 9.6082 & $k_{0}^{b}$ & 26300 \\
$k_{1}^{a}$ & 0.0002 & $k_{1}^{b}$ & 0.62 \\
$k_{2}^{a}$ & -0.0132 & $k_{2}^{b}$ & -39.7 \\
$k_{3}^{a}$ & 0.2257 & $k_{3}^{b}$ & 527 \\
\hline
\end{tabular}

Cases 1 and 2 simultaneously. The voltage loss compared to pure hydrogen increased from 30 to $35 \mathrm{mV}$ when switching from Case 1 to Case 2 (methane treated similar to CO as poisoning species) with $5 \%$ methane in the gas feed at $1.5 \mathrm{~A} \mathrm{~cm}^{-2}$. The addition of $20 \%$ water to the stream led to a voltage loss (compared to pure hydrogen) of $50 \mathrm{mV}$ and $55 \mathrm{mV}$ for Cases 1 and 2, respectively. This means a power density loss of 75 to $82.5 \mathrm{~mW} \mathrm{~cm}^{-2}$. Considering a system power density peak of $250-300 \mathrm{~mW} \mathrm{~cm}^{-2}$ when operating with air at atmospheric pressure, this would mean a loss of ca. $30 \%$ of the generated power density.

\section{Conclusions}

A model of a high temperature PEM fuel cell using PBI membranes has been developed using thermodynamics, transport, and kinetic equations. The model considers mass transport through a thin film electrolyte as well as through the porous media. The incorporation of the thin film layer was crucial for model accuracy, particularly at high current densities and low oxygen concentrations (air). 
Oxygen permeability through the thin electrolyte film varies for a given temperature depending on the equilibrium vapour pressure of the product water above the thin film and, correspondingly, the operating current density, due to variations in oxygen permeability with phosphoric acid concentration (electrolyte film).

The model showed very good agreement with experimental data under various operating conditions and oxygen concentrations. The model emphasises the importance and sensitivity of the electrolyte content on electrode performance, particularly on the cathode. The model is a suitable tool for optimisation of the electrode performance and helps in understanding the reasons behind performance limitations. For example, the model showed that acid doped PBI is not suitable as electrolyte additive for the cathode catalyst layer and that pristine phosphoric acid is preferred. Similarly, the anode can tolerate small quantities (loading) of PBI although excess PBI will lead to severe mass transport limitations.

\section{Appendix}

A summary of $a$ and $b$ constants for (28) is in given Table 3:

$$
\begin{aligned}
& a=a_{1} X^{4}-a_{2} X^{3}+a_{3} X^{2}-a_{4} X+a_{0}, \\
& b=b_{1} X^{4}-b_{2} X^{3}+b_{3} X^{2}-b_{4} X+b_{0} .
\end{aligned}
$$

The pre-exponential factors $A$ and $B$ in (23) and (24) are calculated using

$$
\begin{gathered}
B=\frac{1}{\left(0.00044(\mathcal{W})^{5}-0.01678(\mathcal{W})^{4}+0.2476(\mathcal{W})^{3}-1.7144(\mathcal{W})^{2}+5.8157(\mathcal{W})-7.6626\right)}, \\
A=0.0000025 \exp (1.76593 W),
\end{gathered}
$$

where $(\mathcal{W})$ denotes $(100-W)$. Expressions for the calculation of constants $A$ and $B$ in (39):

$$
\begin{gathered}
A=\exp \left[\left(k_{1}^{a} \mathrm{RH}^{3}\right)+\left(k_{2}^{a} \mathrm{RH}^{2}\right)+\left(k_{3}^{a} \mathrm{RH}\right)+k_{0}^{a}\right], \\
B=\left(k_{1}^{b} \mathrm{RH}^{3}\right)+\left(k_{2}^{b} \mathrm{RH}^{2}\right)+\left(k_{3}^{b} \mathrm{RH}\right)+k_{1}^{b} .
\end{gathered}
$$

\section{List of Symbols}

\section{Latin Letters}

$C_{P t}$ or $C_{\mathrm{O}_{2}}$ : Oxygen concentration in the thin film at platinum-electrolyte boundary/mole $\mathrm{cm}^{3}$

$C_{\text {dissolve: }} \quad$ Oxygen concentration in the thin film at gas pore-electrolyte boundary/mole $\mathrm{cm}^{3}$

$\mathrm{C}_{\mathrm{H} 2}^{0}$ : The reference standard $\mathrm{H}_{2}$ concentration (expressed as $1 / \mathrm{RT}$ ) $/ \mathrm{mol} \mathrm{cm}^{-3} \mathrm{~atm}^{-1}$

$\mathrm{C}_{\mathrm{O}_{2}}^{0}: \quad$ The reference standard $\mathrm{O}_{2}$ concentration (expressed as $1 / \mathrm{RT}$ ) $/ \mathrm{mol} \mathrm{cm}^{-3} \mathrm{~atm}^{-1}$

$D_{\mathrm{O}_{2}}^{\mathrm{PBI}-\mathrm{H} 3 \mathrm{PO} 4}$ : Oxygen diffusion through ionomer/ $/ \mathrm{cm}^{2} \mathrm{~s}^{-1}$

$D_{i j}^{\text {eff: }}: \quad$ The effective binary diffusion $/ \mathrm{cm}^{2} \mathrm{~s}^{-1}$

$E_{c}$ or $E_{a}: \quad$ Activation energy/Kj mole ${ }^{-1}$

$E_{\text {rev }}^{0}: \quad$ Standard cell reversal potential/V

ESA: Electrochemical surface area $/ \mathrm{m}^{2} \mathrm{~g}^{-1}$

F: $\quad$ Faraday constant/coulomb mole ${ }^{-1}$

$\Delta \mathrm{G}^{0}: \quad$ Standard Gibbs free energy of a reaction $/ \mathrm{kJ}$

GDL: Gas diffusion electrode

$H$ : $\quad$ Henry's constant for oxygen solubility in the electrolyte $\mathrm{m}^{3} \mathrm{~atm}$ mole $^{-1}$

$i_{0}$ : The exchange current density/ $\mathrm{A} \mathrm{cm}_{\mathrm{Pt}}^{-2}$ (ESA)

$i_{0}^{\mathrm{CO}}: \quad$ Exchange current density for hydrogen oxidation after $\mathrm{CO}$ poisoning

$i_{0}^{\text {ref: }} \quad$ The exchange current density at reference temperature/ $\mathrm{A} \mathrm{cm}-2$ $j_{\text {crossover: }}$ Crossover current (rate)/ $/ \mathrm{A} \mathrm{cm}^{-2}$ (geometric)

$j_{\text {lim }}: \quad$ Limiting current density $/ \mathrm{A} \mathrm{cm}^{-2}$ (geometric)

$j: \quad$ Current density $/ \mathrm{A} \mathrm{cm}^{2}$ (geometric)

$L_{c}$ : The catalyst loading, weight of platinum per unit area $/ \mathrm{g} \mathrm{cm}^{-2}$

$M: \quad$ The molecular weight of the gas $/ \mathrm{g} \mathrm{mole}^{-1}$

$M_{\mathrm{H} 3 \mathrm{PO} 4}$ : The mass of acid per unit area/ $/ \mathrm{mg} \mathrm{cm}^{2}$ (geometric)

$M_{\mathrm{PBI}}$ : The mass of PBI per unit area (PBI loading) $/ \mathrm{mg} \mathrm{cm}^{2}$ (geometric)

$N_{i}: \quad$ The molar flux of species $i / \mathrm{mole} \mathrm{s}^{-1} \mathrm{~cm}^{-2}$ (geometric)

$n: \quad$ Number of electrons involved in the reaction

$P_{\mathrm{O}_{2}}: \quad$ Oxygen partial pressure/atm

$P_{c}$ : $\quad$ The gas critical temperature and pressure/atm

$P_{\mathrm{H}_{2} \mathrm{O}}^{*}: \quad$ The saturation vapour pressure of pure water at given temperature/atm

PRU: Number of doped acid molecules per repeat polymer unit

$R: \quad$ Gas constant $/ \mathrm{J} \mathrm{K}^{-1} \mathrm{~mol}^{-1}$

RH: $\quad$ Relative humidity $/ \%$

$S_{c}$ : $\quad$ The specific surface area of carbon per unit area/dimensionless

$S_{A}: \quad$ The surface area $/ \mathrm{m}^{2} \mathrm{~g}^{-1}$

$T: \quad$ Temperature/K

$T_{c}$ : $\quad$ Gas critical temperature/ $\mathrm{K}$

$T_{\text {ref: }} \quad$ The reference temperature where $i_{0}^{\text {ref }}$ is measured/K

$U_{\text {cell }}: \quad$ Cell potential/V

$V: \quad$ Potential versus SHE/V

$W: \quad$ Phosphoric acid weight concentration/wt \%

$X_{i}: \quad$ The molar fraction of species $i$

$X: \quad$ Phosphoric acid molar concentration/mole $\%$. 


\section{Greek Symbols}

$\alpha: \quad$ Transfer coefficient

$\alpha_{a}$ and $\alpha_{c}$ : Transfer coefficient for anodic and cathodic reactions

$\alpha_{\mathrm{H}_{2} \mathrm{O}}: \quad$ The water activity

$\alpha_{\mathrm{H}_{2} \mathrm{O}}^{0}$ : The reference standard water activity (unity)

$\gamma: \quad$ The pressure coefficient or the reaction order

$\delta$ : $\quad$ Average ionomer film thickness covering a catalyst particle/m

$\varepsilon: \quad$ The porosity/\%

$\eta: \quad$ Overpotential/V

$\eta_{a}: \quad$ Anode overpotential/V

$\eta_{c}: \quad$ Cathode overpotential/V

$\eta_{\text {crossover }}$ : Cross over potential loss/V

$\rho: \quad$ The density/g $\mathrm{cm}^{3}$

$\sigma: \quad$ Conductivity/S $\mathrm{cm}^{-1}$

$\tau: \quad$ The tortuosity

$\theta_{\mathrm{CO}}: \quad$ Surface coverage by $\mathrm{CO}$.

\section{Acknowledgments}

EPSRC through the SUPERGEN Fuel cell Consortium and the EU through the FP6 project FURIM supported this paper.

\section{References}

[1] D. M. Bernardi and M. W. Verbrugge, "Mathematical model of the solid-polymer-electrolyte fuel cell," Journal of the Electrochemical Society, vol. 139, no. 9, pp. 2477-2491, 1992.

[2] T. Mennola, M. Noponen, M. Aronniemi et al., "Mass transport in the cathode of a free-breathing polymer electrolyte membrane fuel cell," Journal of Applied Electrochemistry, vol. 33, no. 11, pp. 979-987, 2003.

[3] T. Hottinen, M. Noponen, T. Mennola, O. Himanen, M. Mikkola, and P. Lund, "Effect of ambient conditions on performance and current distribution of a polymer electrolyte membrane fuel cell," Journal of Applied Electrochemistry, vol. 33, no. 3-4, pp. 265-271, 2003.

[4] G. H. Guvelioglu and H. G. Stenger, "Computational fluid dynamics modeling of polymer electrolyte membrane fuel cells," Journal of Power Sources, vol. 147, no. 1-2, pp. 95-106, 2005.

[5] Y. P. Sun and K. Scott, "The influence of mass transfer on a porous fuel cell electrode," Fuel Cells, vol. 4, no. 1-2, pp. 3038, 2004.

[6] S. Mazumder and J. V. Cole, "Rigorous 3-D mathematical modeling of PEM fuel cells I. Model predictions without liquid water transport," Journal of the Electrochemical Society, vol. 150, no. 11, pp. A1503-A1509, 2003.

[7] J. C. Amphlett, R. M. Baumert, R. F. Mann, B. A. Peppley, P. R. Roberge, and T. J. Harris, "Performance modeling of the Ballard Mark IV solid polymer electrolyte fuel cell I. Mechanistic model development," Journal of the Electrochemical Society, vol. 142, no. 1, pp. 1-8, 1995.

[8] M. Noponen, E. Birgersson, J. Ihonen, M. Vynnycky, A. Lundblad, and G. Lindbergh, "A two-phase non-isothermal PEFC model: theory and validation," Fuel Cells, vol. 4, no. 4, pp. 365-377, 2004.
[9] E. Birgersson, M. Noponen, and M. Vynnycky, "Analysis of a two-phase non-isothermal model for a PEFC," Journal of the Electrochemical Society, vol. 152, no. 5, pp. A1021-A1034, 2005.

[10] S. Mazumder and J. V. Cole, "Rigorous 3-D mathematical modeling of PEM fuel cells II. Model predictions with liquid water transport," Journal of the Electrochemical Society, vol. 150, no. 11, pp. A1510-A1517, 2003.

[11] P. Argyropoulos, K. Scott, and W. M. Taama, "Onedimensional thermal model for direct methanol fuel cell stacks. Part I. Model development," Journal of Power Sources, vol. 79, pp. 169-183, 1999.

[12] R. M. Rao, D. Bhattacharyya, R. Rengaswamy, and S. R. Choudhury, "A two-dimensional steady state model including the effect of liquid water for a PEM fuel cell cathode," Journal of Power Sources, vol. 173, no. 1, pp. 375-393, 2007.

[13] M. Hu, X. Zhu, M. Wang, A. Gu, and L. Yu, "Analysis and discussion of the internal transport mechanism," Energy Conversion and Management, vol. 45, pp. 1883-1916, 2004.

[14] M. Hu, A. Gu, M. Wang, X. Zhu, and L. Yu, "Three dimensional, two phase flow mathematical model for PEM fuel cell: part I. Model development," Energy Conversion and Management, vol. 45, pp. 1861-1882, 2004.

[15] D. Cheddie and N. Munroe, "Parametric model of an intermediate temperature PEMFC," Journal of Power Sources, vol. 156, no. 2, pp. 414-423, 2006.

[16] D. Cheddie and N. Munroe, "Mathematical model of a PEMFC using a PBI membrane," Energy Conversion and Management, vol. 47, pp. 1490-1504, 2006.

[17] D. F. Cheddie and N. D. H. Munroe, "Three dimensional modeling of high temperature PEM fuel cells," Journal of Power Sources, vol. 160, no. 1, pp. 215-223, 2006.

[18] K. Scott, S. Pilditch, and M. Mamlouk, "Modelling and experimental validation of a high temperature polymer electrolyte fuel cell," Journal of Applied Electrochemistry, vol. 37, no. 11, pp. 1245-1259, 2007.

[19] J. Hu, H. Zhang, J. Hu, Y. Zhai, and B. Yi, “Two dimensional modeling study of $\mathrm{PBI} / \mathrm{H} 3 \mathrm{PO} 4$ high temperature PEMFCs based on electrochemical methods," Journal of Power Sources, vol. 160, no. 2, pp. 1026-1034, 2006.

[20] J. Hu, H. Zhang, Y. Zhai, G. Liu, J. Hu, and B. Yi, "Performance degradation studies on $\mathrm{PBI} / \mathrm{H} 3 \mathrm{PO} 4$ high temperature PEMFC and one-dimensional numerical analysis," Electrochimica Acta, pp. 394-401, 2006.

[21] M. B. Cutlip, S. C. Yang, and P. Stonehart, "Simulation and optimization of porous gas-diffusion electrodes used in hydrogen oxygen phosphoric acid fuel cells-II development of a detailed anode model," Electrochimica Acta, vol. 36, no. 3-4, pp. 547-553, 1991.

[22] J. Lobato, P. Cañizares, M. A. Rodrigo, J. J. Linares, C.G. Piuleac, and S. Curteanu, "The neural networks based modeling of a polybenzimidazole-based polymer electrolyte membrane fuel cell: effect of temperature," Journal of Power Sources, vol. 192, no. 1, pp. 190-194, 2009.

[23] M. Mamlouk and K. Scott, "Characterisation of oxygen reduction on carbon supported platinum electrodes at a $\mathrm{PBI} /$ phosphoric acid interface," submitted to Journal of Applied Electrochemistry.

[24] Z. Liu, J. S. Wainright, M. H. Litt, and R. F. Savinell, "Study of the oxygen reduction reaction (ORR) at $\mathrm{Pt}$ interfaced with phosphoric acid doped polybenzimidazole at elevated temperature and low relative humidity," Electrochimica Acta, vol. 51, no. 19, pp. 3914-3923, 2006. 
[25] Z. Liu, J. S. Wainright, and R. F. Savinell, "High-temperature polymer electrolytes for PEM fuel cells: study of the oxygen reduction reaction (ORR) at a Pt-polymer electrolyte interface," Chemical Engineering Science, vol. 59, no. 22-23, pp. 4833-4838, 2004.

[26] A. J. Appleby, "Evolution and reduction of oxygen on oxidized platinum in $85 \%$ orthophosphoric acid," Journal of Electroanalytical Chemistry and Interfacial Electrochemistry, vol. 24, p. 97, 1970.

[27] J. C. Haung, R. K. Sen, and E. Yeager, "Oxygen reduction on platinum in $85 \%$ orthophosphoric acid," Journal of The Electrochemical Society, vol. 126, no. 5, pp. 786-792, 1979.

[28] S. J. Clouser, J. C. Huang, and E. Yeager, "Temperature dependence of the Tafel slope for oxygen reduction on platinum in concentrated phosphoric acid," Journal of Applied Electrochemistry, vol. 23, no. 6, pp. 597-605, 1993.

[29] A. J. Appleby, "Oxygen reduction on oxide-free platinum in $85 \%$ orthophosphoric acid: temperature and impurity dependence," Journal of the Electrochemical Society, vol. 117, pp. 328-335, 1970.

[30] N. Sugishima, J. T. Hinatsu, and F. R. Foulkes, "Phosphorous acid impurities in phosphoric acid fuel cell electrolytes. II. Effects on the oxygen reduction reaction at platinum electrodes," Journal of the Electrochemical Society, vol. 141, no. 12, pp. 3332-3335, 1994.

[31] J. McBreen, W. E. O'Grady, and R. Richter, “A rotating disk electrode apparatus for the study of fuel cell reactions at elevated temperatures and pressures," Journal of the Electrochemical Society, vol. 131, pp. 1215-1216, 1984.

[32] B. R. Scharifker, P. Zelenay, and J. O. Bockris, "Kinetics of oxygen reduction in molten phosphoric acid at high temperatures," Journal of the Electrochemical Society, vol. 134, no. 11, pp. 2714-2725, 1987.

[33] A. R. Korsgaard, R. Refshauge, M. P. Nielsen, M. Bang, and S. K. KÆ, "Experimental characterization and modeling of commercial polybenzimidazole-based MEA performance," Journal of Power Sources, vol. 162, no. 1, pp. 239-245, 2006.

[34] W. E. O'Grady, E. J. Taylor, and S. Srinivasan, "Electroreduction of oxygen on reduced platinum in $85 \%$ phosphoric acid," Journal of Electroanalytical Chemistry, vol. 132, pp. 137-150, 1982.

[35] T. Sousa, M. Mamlouk, and K. Scott, "An isothermal model of a laboratory intermediate temperature fuel cell using PBI doped phosphoric acid membranes," Chemical Engineering Science, vol. 65, no. 8, 2010.

[36] K. Scott and M. Mamlouk, "A cell voltage equation for an intermediate temperature proton exchange membrane fuel cell," International Journal of Hydrogen Energy, vol. 34, pp. 9195-9202, 2009.

[37] D. Weng, J. S. Wainright, U. Landau, and R. F. Savinell, "Electro-osmotic drag coefficient of water and methanol in polymer electrolytes at elevated temperatures," Journal of the Electrochemical Society, vol. 143, no. 4, pp. 1260-1263, 1996.

[38] J. C. Slattery and R. B. Bird, "Calculation of the diffusion coefficient of dilute gases and the self-diffusion coefficient of dense gases," American Institute of Chemical Engineers Journal, vol. 4, no. 2, pp. 137-142, 1958.

[39] W. Vogel, L. Lundquist, P. Ross, and P. Stonehart, "Reaction pathways and poisons-II. The rate controlling step for electrochemical oxidation of hydrogen on $\mathrm{Pt}$ in acid and poisoning of the reaction by CO," Electrochimica Acta, vol. 20, no. 1, pp. 79-93, 1975.
[40] H. P. Dhar, L. G. Christner, A. K. Kush, and H. C. Maru, "Performance study of a fuel cell Pt-on-C Anode in presence of $\mathrm{CO}$ and $\mathrm{CO} 2$, and calculation of adsorption parameters for CO poisoning," Journal of the Electrochemical Society, vol. 133, no. 8, pp. 1574-1582, 1986.

[41] K. Klinedinst, J. A. S. Bett, J. Macdonald, and P. Stonehart, "Oxygen solubility and diffusivity in hot concentrated H3PO4," Journal of Electroanalytical Chemistry, vol. 57, no. 3, pp. 281-289, 1974.

[42] M. A. Enayetullah, T. D. DeVilbiss, and J. O. M. Bockris, "Activation parameters for oxygen reduction kinetics in trifluoromethane sulfonic acid systems," Journal of the Electrochemical Society, vol. 136, no. 11, pp. 3369-3376, 1989.

[43] P. Zelenay, B. R. Scharifker, and O. M. Bockris, "Comparison of the properties of $\mathrm{cf} / / 3 \mathrm{so} / / 3 \mathrm{~h}$ and $\mathrm{h} / / 3 \mathrm{po} / / 4$ in relation to fuel cells," Journal of the Electrochemical Society, vol. 133, no. 11, pp. 2262-2267, 1986.

[44] M. Razaq, A. Razaq, E. Yeager, D. D. Desmarteau, and S. Singh, "Oxygen electroreduction in perfluorinated sulphonyl imides," Journal of Applied Electrochemistry, vol. 17, no. 5, pp. 1057-1064, 1987.

[45] D. I. MacDonald and J. R. Boyack, "Density, electrical conductivity, and vapor pressure of concentrated phosphoric acid," Journal of Chemical and Engineering Data, vol. 14, no. 3, pp. 380-384, 1969.

[46] H. R. Kunz and G. A. Gruver, "Catalytic activity of platinum supported on carbon for electrochemical oxygen reduction in phosphoric acid," Journal of the Electrochemical Society, vol. 122, no. 10, pp. 1279-1287, 1975.

[47] A. J. Appleby, "Oxygen reduction on active platinum in $85 \%$ orthophosphoric acid," Journal of The Electrochemical Society, vol. 117, pp. 641-645, 1970.

[48] J. O. 'M. Bockris and A. Gochev, "Temperature dependence of the symmetry factor in electrode kinetics," Journal of Electroanalytical Chemistry, vol. 214, no. 1-2, pp. 655-674, 1986.

[49] F. Barbir, PEM Fuel Cells: Theory and Practice, Sustainable World Series, Elsevier Academic Press, London, UK, 2005.

[50] H. P. Dhar, L. G. Christner, and A. K. Kush, "Nature of CO adsorption during $\mathrm{H}-2$ oxidation in relation to modelling for CO poisoning of a fuel cell anode," Journal of the Electrochemical Society, vol. 134, no. 12, pp. 3021-3026, 1987.

[51] G. Kohlmayr and P. Stonehart, "Adsorption kinetics for carbon monoxide on platinum in hot phosphoric acid," Electrochimica Acta, vol. 18, no. 2, pp. 211-223, 1973.

[52] Q. Li, R. He, J.-A. Gao, J. O. Jensen, and N. J. Bjerrum, “The $\mathrm{CO}$ poisoning effect in PEMFCs operational at temperatures up to $200^{\circ}$ C," Journal of the Electrochemical Society, vol. 150, no. 12, pp. A1599-A1605, 2003.

[53] M. G. Sustersic, R. Cordova O, W. E. Triaca, and A. J. Arvia, "Electrosorption of methane and its potentiodynamic electrooxidation on platinized platinum," Journal of the Electrochemical Society, vol. 127, no. 6, pp. 1242-1248, 1980.

[54] L. W. Niedrach, "Galvanostatic and volumetric studies of hydrocarbons adsorbed on fuel cell anodes," Journal of The Electrochemical Society, vol. 111, pp. 1309-1317, 1964.

[55] A. H. Taylor and S. B. Brummer, "The adsorption and oxidation of hydrocarbons on noble metal electrodes. VII. Oxidative adsorption of methane on platinum electrodes," Journal of Physical Chemistry, vol. 72, no. 8, pp. 2856-2862, 1968.

[56] S. Y. Hsieh and K. M. Chen, "Anodic oxidation of methane," Journal of the Electrochemical Society, vol. 124, no. 8, pp. 11711174, 1977. 
[57] J.-L. Souquet, M. Duclot, and M. Levy, "Salt-polymer complexes: strong or weak electrolytes?" Solid State Ionics, vol. 85, no. 1-4, pp. 149-157, 1996.

[58] Y. L. Ma, "The Fundamental Studies of Polybenzimidazole/Phosphoric Acid Polymer Electrolyte For Fuel Cells," Ph.D. thesis, Case Western Reserve University, Cleveland, Ohio, USA, 2004.

[59] R. Bouchet and E. Siebert, "Proton conduction in acid doped polybenzimidazole," Solid State Ionics, vol. 118, no. 3-4, pp. 287-299, 1999.

[60] R. Bouchet, S. Miller, M. Duclot, and J. L. Souquet, "A thermodynamic approach to proton conductivity in aciddoped polybenzimidazole," Solid State Ionics, vol. 145, no. 1-4, pp. 69-78, 2001.

[61] Y.-L. Ma, J. S. Wainright, M. H. Litt, and R. F. Savinell, "Conductivity of PBI membranes for high-temperature polymer electrolyte fuel cells," Journal of the Electrochemical Society, vol. 151, no. 1, pp. A8-A16, 2004

[62] M. Mamlouk and K. Scott, "What should we blame?" International Journal of Hydrogen Energy, vol. 35, pp. 784-793, 2010. 


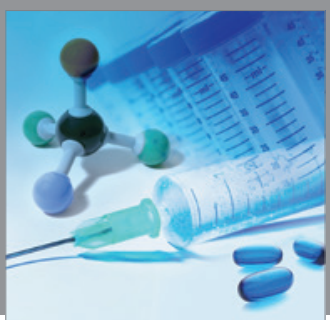

International Journal of

Medicinal Chemistry

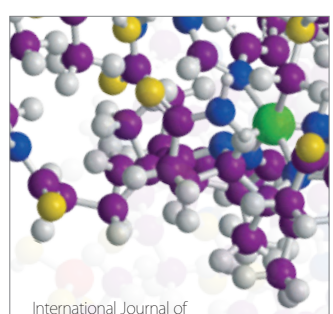

Carbohydrate Chemistry

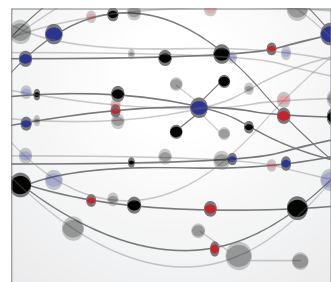

The Scientific World Journal
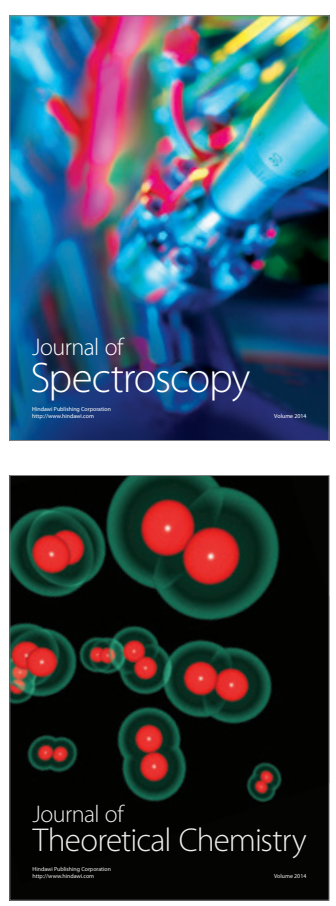
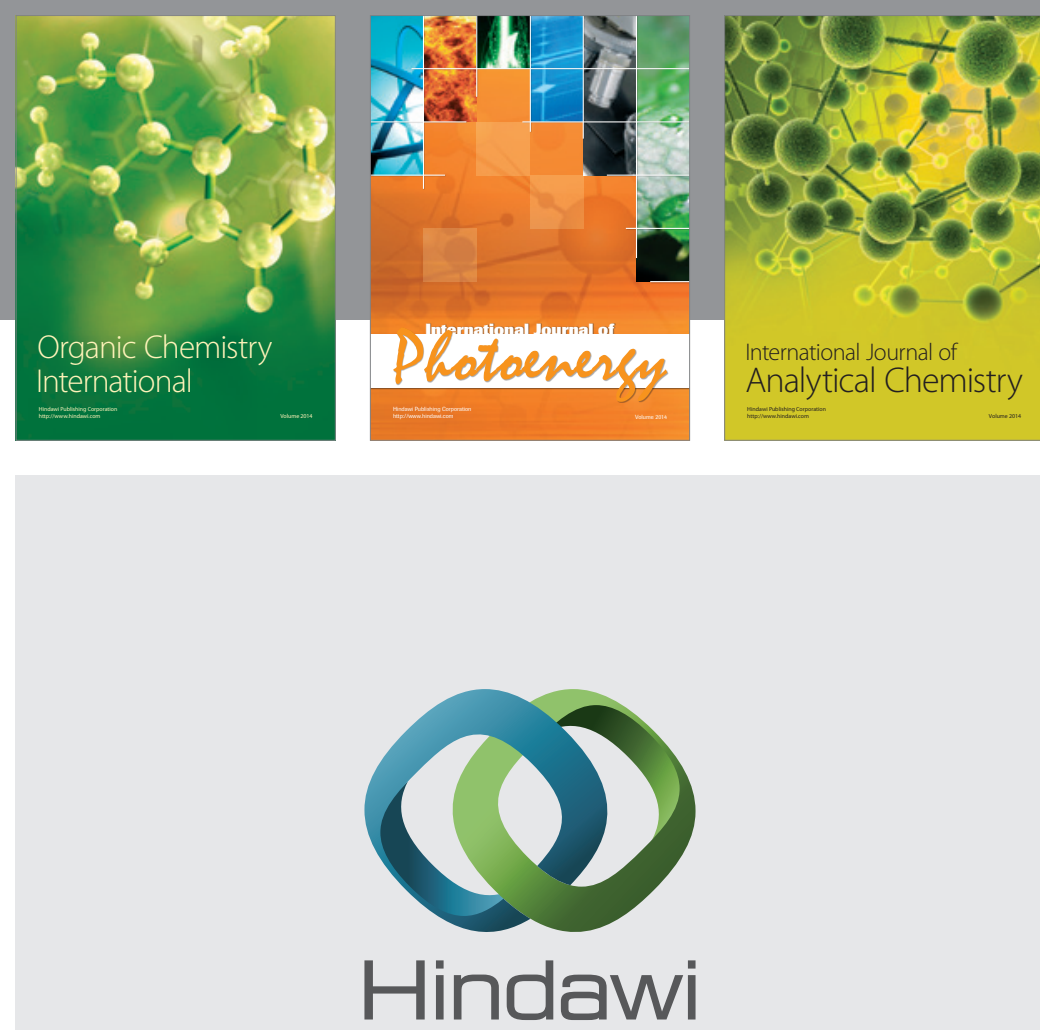

Submit your manuscripts at

http://www.hindawi.com
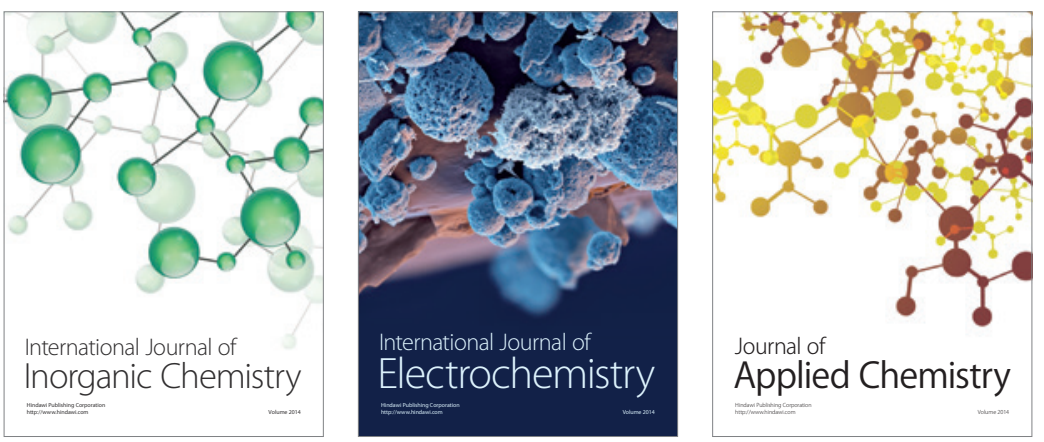

Journal of

Applied Chemistry
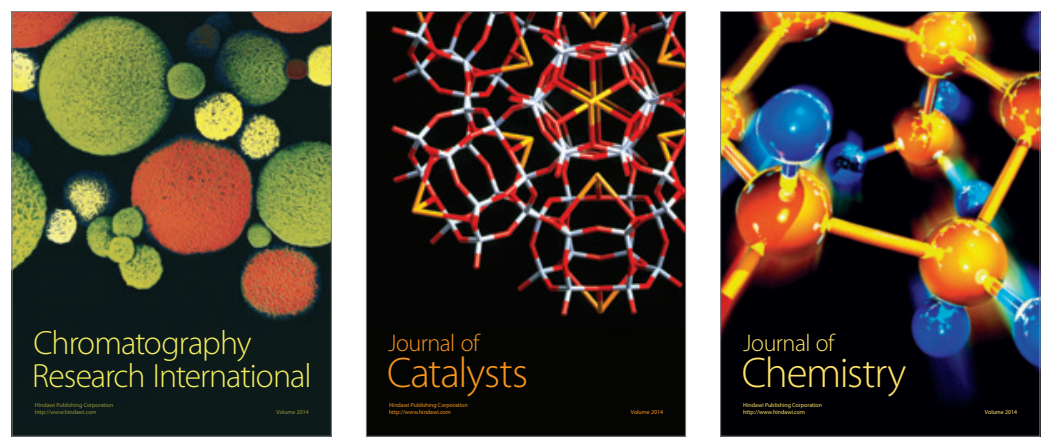
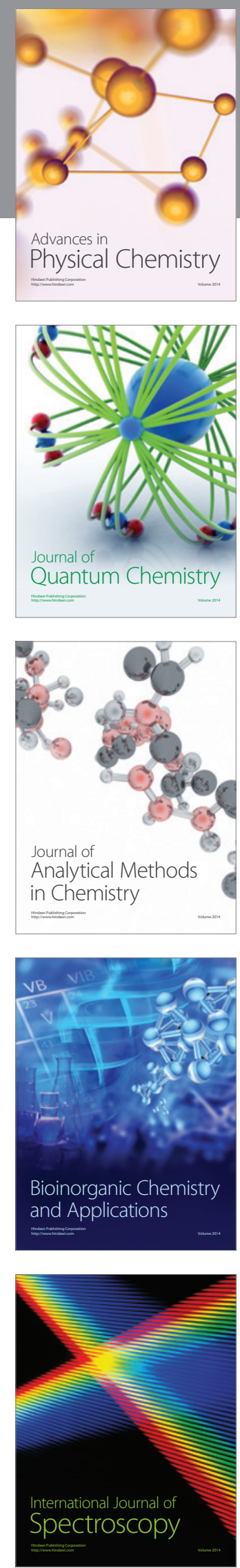